\title{
Review Paper: \\ Effects of Extracorporeal Shockwave Therapy on Clinical and Neurophysi- ological Indices of Spasticity Inpatients With Upper Motor Neuron Lesions: A Systematic Review and Meta-analysis
}

\author{
Fereshteh Poursaeed $^{1}$ (D), *Nahid Tahan² ${ }^{2}$, Farideh Dehghan Manshadi², Ali Reza Akbarzade Bagheban ${ }^{3}$ (i) \\ 1. Department of Physical Therapy, School of Professional Studies, Northeastern University, Boston, Massachusetts, USA. \\ 2. Department of Physiotherapy, School of Rehabilitation, Shahid Beheshti University of Medical Sciences, Tehran, Iran. \\ 3. Department of Biostatistics, Proteomics Research Center, School of Allied Medical Sciences, Shahid Beheshti University of Medical Sciences,Tehran, Iran.
}

\begin{tabular}{l|l}
$\begin{array}{c}\text { Use your device to scan } \\
\text { and read the article online }\end{array}$ \\
$\begin{array}{l}\text { Crtation Poursaeed F, Tahan N, Dehghan Manshadi F, Akbarzade Bagheban AR. [Effects of Extracorporeal Shockwave Ther- } \\
\text { apy on Clinical and Neurophysiological Indices of Spasticity Inpatients With Upper Motor Neuron Lesions: A Systematic Review } \\
\text { and Meta-analysis (Persian)]. Archives of Rehabilitation. 2021; 22(1):28-47. https://doi.org/10.32598/RJ.22.1.3257.1 }\end{array}$ \\
doi https://doi.org/10.32598/RJ.22.1.3257.1
\end{tabular}

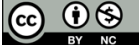

Received: 24 Sep 2020 Accepted: 15 Dec 2020 Available Online: 01 Apr 2021

Keywords: Spasticity, Cerebral palsy, Stroke, Multiple sclerosis, Extracorporeal shock wave therapy

\begin{abstract}
Objective Spasticity is one of the components of an Upper Motor Neuron (UMN) lesion that occurs usually after a period of flaccidity in the form of velocity-dependent resistance to passive stretch. Spasticity is a significant cause of limited mobility and disability in neurological diseases. There are several clinical approaches to control spasticity. Recently, Shock Wave Therapy (SWT) has been reported to be a new, safe, and effective method for reducing spasticity for people with upper motor neuron lesions. We conducted a meta-analysis of relevant clinical trials to assess the effect of applying SWT on spasticity in UMN lesions. Materials \& Methods An electronic search was performed in PubMed, ISI Web of Science, Scopus, Science Direct, MEDLINE, and Google scholar from January 2005 to January 2020. Studies were included if they measured spasticity with the Modified Ashworth Scale (MAS) or/and neurophysiological indices in patients with stroke, multiple sclerosis, and cerebral palsy. The keywords of muscle hypertonia or spasticity, extracorporeal shock wave therapy, stroke, multiple sclerosis, and cerebral palsy were used. Two independent researchers searched articles, screened eligible studies against the inclusion criteria, and assessed the methodological quality of included studies. The methodological quality of studies was evaluated using the Downs and Black tool. The difference between the means was considered as the effect size in the MAS and Hoffman reflex/motor response $(H / M)$ ratio before and after the intervention with $95 \% \mathrm{Cl}$ in random-effects models. Analyzes were performed using STATA software version 11.

Results The initial search led to the retrieval of 98 studies based on the inclusion and exclusion criteria, of which 24 full-text articles were reviewed and 14 articles were included in the meta-analysis process. All 14 articles had examined the effects of shockwave on the MAS. Four studies with 120 patients had examined the effects of shockwave therapy on the $\mathrm{H} / \mathrm{M}$ ratio. Significant reduction in MAS grade was observed immediately $\left[I^{2}=100 \%, P<0.001, S M D=1.38\right.$ with $\left.95 \% \mathrm{Cl}:(0.80,1.87)\right]$ and three months after SWT $\left[I^{2}=\right.$ $100 \%, \mathrm{P}<0.001, \mathrm{SMD}=1.13$ with $95 \% \mathrm{Cl}:(0.50,1.76)]$ in comparison with the baseline values. ESWT had no significant effects on the $\mathrm{H} / \mathrm{M}$ ratio $\left[I^{2}=97.5 \%, \mathrm{P}<0.001, \mathrm{SMD}=1.09\right.$ with $\left.95 \% \mathrm{Cl}:(-0.54,2.73)\right]$.

Conclusion SWT can improve spasticity based on the MAS. The lack of SWT effects on the neurophysiological parameter of spasticity supports this opinion that SWT acts on the non-neural component of spasticity. Differences observed in studies in terms of treatment sessions, intervals of treatment sessions, energy density, number of shocks, and follow-up duration need to be examined more closely. More randomized clinical trials are needed in the future to analyze the impact of these factors on the efficacy of SWT for spastic patients.
\end{abstract}

\section{* Corresponding Author:}

Nahid Tahan, PhD.

Address: Department of Physiotherapy, School of Rehabilitation, Shahid Beheshti University of Medical Sciences, Tehran, Iran

Tel: +98 (21) 77561723

E-Mail: nahidta2431@gmail.com 


\section{Extended Abstract}

\section{Introduction}

pasticity is one of the symptoms of upper motor neuron damage that usually appears after a period of muscle relaxation as an increase in speed-dependent resistance during patio movement with the intensification of tendon reflexes [1]. This movement disorder is commonly seen in patients with cerebral palsy, hemiplegia, multiple sclerosis, and spinal cord injuries. Neural and non-neural mechanisms can lead to increased resistance to patio movement in upper motor neuron injury. Nervous mechanisms are due to the removal of inhibition of the cortical-spinal pyramidal pathway and extra-pyramidal pathways (rubrospinal and vestibulospinal) from the brain stem and spinal cord [6], but non-neural mechanisms are associated with muscle stiffness and high levels of collagen and connective tissue in the spastic muscle [2]. Prolonged spasticity can cause changes in the structural properties of the involved muscle and adjacent muscles in a short time or muscle fibrosis, which causes abnormal control of the position of the limb and as a result, movement disorder in the limb [7].

Pharmacotherapy and rehabilitation interventions, especially those that focus on connective tissue flexibility, are non-invasive treatments to reduce spasticity [8]. Shock Wave Therapy (SWT) is one of the most promising methods to reduce spasticity today, but it has not yet been used as a common treatment $[9,10]$. Shockwaves are high-energy sound waves (100 MPA) that are produced in a very short time (10 microseconds) and at high pressure [11]. Shockwaves have been reported in the treatment of orthopedic lesions, such as nonunion in long bones, inflammation of the plantar fascia, calcified shoulder tendonitis, inflammatory tendon diseases, and spasticity [12]. SWT can be used in both focal and radial forms. Focal shockwaves are generated by electromagnetic, hydroelectric, and piezoelectric methods, while radial shockwaves are generated pneumatically. In addition, the penetration depth of radial shockwaves is less than focal shockwaves [11].

So far, no precise mechanism has been proposed to justify the effects of SWT in reducing spasticity. A group of studies believes that "shockwave" shock waves can have a direct effect on fibrosis muscles and non-reflex components of spastic muscle. This mechanism of shock wave effect can be explained by the results of some studies on the positive effects of SWT on the tendon and musculoskeletal problems in patients with hypertension [13]. Some studies have shown that shockwaves at the muscle level can alter the sensory flow of the muscle, which by acting on free nerve terminals, reduces muscle excitability at the spinal cord level and ultimately reduces spasticity [14]. Studies on non-human specimens have shown that shockwave delays neuromuscular transmission at the neuromuscular junction and is a possible mechanism for reducing muscle pain and tonicity [15]. There are various clinical tools and neurophysiological methods for assessing spasticity. Evaluation of neurophysiological responses of spastic muscle is possible by examining tendon reflex, $\mathrm{F}$ wave, $\mathrm{M}$ wave, and Hoffman reflex [16, 17].

The Ashworth scale is a common tool for the clinical assessment of spasticity, which is based on the assessment of patio joint resistance [18]. Most studies on the effects of SWT on muscle tone have used the clinical scale of Ashworth or biomechanical scales and only in two studies, evaluation was performed by measuring ultrasound of muscle architecture [19, 20].

Due to the need for spasticity treatment in neurological patients and because in clinical studies on the effect of SWT on the reduction of spastic muscle tone, no specific treatment protocol has been used, and also because systematic reviews and meta-analysis are tools for summarizing the available evidence accurately and reliably [21], the present study was done to analyze the available clinical trial studies on the effectiveness of SWT in reducing spastic muscle tone at the time immediately and three months after shockwave application in patients with upper motor neuron lesions.

\section{Materials and Methods}

In this study, databases, including PubMed, ISI Web of Science, ScienceDirect, MEDLINE, Scopus, and Google Scholar search engine were searched using the keywords of muscle hypertension or spasticity, cerebral palsy, stroke, multiple sclerosis, and shockwave therapy. All clinical trials published from January 2005 to January 2020 were enrolled. Studies examining spasticity with a modified Ashworth Scale (MAS) and/or neurophysiological parameters in patients with stroke, cerebral palsy, and multiple sclerosis were selected. Two independent researchers searched and reviewed eligible studies in terms of inclusion criteria and assessed the methodological quality of selected studies.

First, the abstracts were reviewed, and then, the full text of the articles was reviewed based on the inclusion criteria. Studies unavailable in their full-text form, those published in a non-English language, and studies, in which shockwave had been used for purposes other than spasticity treatment were excluded from the study. Articles with the following characteristics were selected for meta-analysis: 1. Original research articles; 2 . Clinical trial studies with 
a control group or pre-test/post-test design; 3. Studies using the MAS to assess spasticity (at least two times, one immediately after the intervention and the other, 3 months after SWT; and 4. studies using neurophysiological indicators to assess spasticity. The methodological quality of the selected studies was assessed using the Downs and Black Scale. This scale consists of 27 items and is designed to evaluate the methodological quality of random and nonrandom studies [22].

\section{Statistical analysis}

The difference between the means was considered as the effect size in the scores of the joint Ashworth scale before, immediately, and three months after the intervention for meta-analysis. Another meta-analysis was performed on the differences in means in neurophysiological indices before and after the intervention. Heterogeneity was assessed (presence or absence of homogeneity) between studies using the $\mathrm{I}^{2}$ index. Due to the confirmation of heterogeneity of studies ( $\mathrm{P}>50 \%)$ using the Ashworth scale and neurophysiological indices, the random-effects model of the meta-analysis was used. This model shows the mean difference of each study and the value of the combined mean difference as well as their confidence intervals. Emission bias was also assessed using Egger's test. Data were analyzed using STATA software version 11. Values of $p$ less than 0.05 were considered statistically significant.

\section{Results}

Using the above keywords, a total of 98 articles were selected in the first stage, which after deleting 31 unrelated articles and 43 duplicate articles, 24 articles remained. Among these articles, the full text of two articles was not found, and three articles were clinical trials on animals. The other five articles were omitted for the following reasons: three studies did not report mean values and Standard Deviation ( \pm SD) and two articles used the MAS. A total of 14 articles were included in the systematic review and meta-analysis. The flowchart of the selection process of studies is shown in Figure 1. All related studies were analyzed in terms of patient characteristics, treatment sessions, muscles examined, intensity and number of treatment pulses, evaluation methods, and finally the res ults obtained (Table 1). The quality of the studies entered varied. Based on the Downs and Black score, one excellent study, two good studies, seven relatively good low-quality, and four low-quality studies were determined. The mean score of methodological quality in all studies was 17 and in the range of 10-27. Table 1 shows the qualitative scores of all studies.

\section{Systematic review findings}

As shown in Table 1, the observed differences between the articles are in the type of disease, the number of treatment sessions, the muscles examined, and the energy applied. Out of 14 articles included in the study, 11 articles had examined the effect of shockwave in stroke patients, one study in multiple sclerosis patients, and 3 studies in cerebral palsy patients, which is probably due to the higher prevalence of stroke patients in the community. The number of treatment sessions in 7 studies was one and in other studies, the duration of treatment lasted between 3 and 6 weeks. The highest number of sessions was found in the study by Wang et al. with one session of treatment per week for 3 months and a total of 12 sessions [23]. In terms of the duration of the therapeutic effects of shockwave, Moon et al. concluded that the effect of SWT decreases over time [24]. While studies by Manganotti et al. [25] and Amelio et al. [26] confirmed the long-term effects of shockwave. In terms of examined muscles, the gastrocolic muscle had been studied in eight studies, wrist and finger flexor muscles in 5 studies, and biceps muscle in one study. The difference in the parameters of the shock wave device in terms of energy intensity used varied from $0.03 \mathrm{~mJ} / \mathrm{mm}^{2}$ to $0.32 \mathrm{~mJ} /$ $\mathrm{mm}^{2}$. In most studies, low energy intensities had been used in the treatment, but no reason had been provided by the researcher in choosing the intensity of application.

A total of 12 studies had evaluated the effect of SWT on the scores of the MAS. Among these articles, 3 studies had evaluated the effect of SWT three months after treatment using this scale [25-27]. Manganotti simultaneously evaluated two groups of forearm flexor and intrinsic hand muscles [25]. In his study, Wang evaluated the right and left gastrocnemius muscles separately [23]. Li examined the intrinsic muscles of the hand in 2 groups and the forearm flexor muscles in 2 groups [27].

\section{Meta-analysis findings}

A. Analysis of the results of studies included in the meta-analysis by examining the effect of shockwave on the scores of the modified Ashworth scale:

A total of 18 interventions that evaluated the effect of shockwave on the MAS scores before and after treatment and 7 studies that examined the effect of shockwave on the MAS scores before and three months after SWT were included in the meta-analysis.

The results of the meta-analysis showed a significant decrease in the MAS immediately after treatment; however, the Ashworth scale scores decreased by 1.38 with a $95 \%$ 
Table 1. Studies on the use of shockwave to reduce spasticity in patients with neurological lesions

\begin{tabular}{|c|c|c|c|c|c|c|c|c|c|c|}
\hline \multirow{3}{*}{$\begin{array}{l}\text { Author/ } \\
\text { Year of } \\
\text { Publication }\end{array}$} & \multirow{3}{*}{$\begin{array}{l}\text { Type of } \\
\text { Disease/ } \\
\text { Number of } \\
\text { Patients }\end{array}$} & \multirow{3}{*}{$\begin{array}{c}\text { Treatment } \\
\text { Dose (Num- } \\
\text { ber of Shots)/ } \\
\text { Treated } \\
\text { Muscles }\end{array}$} & \multirow{3}{*}{$\begin{array}{l}\text { Number of Treat- } \\
\text { ment Sessions/Treat- } \\
\text { ment Methods }\end{array}$} & \multirow{3}{*}{$\begin{array}{l}\text { Article } \\
\text { Quality } \\
\text { Score }\end{array}$} & \multirow{3}{*}{$\begin{array}{c}\text { Applied } \\
\text { Energy } \\
\left(\mathrm{mJ} / \mathrm{mm}^{2}\right)\end{array}$} & \multicolumn{5}{|c|}{ Mean $\pm S D$} \\
\hline & & & & & & \multicolumn{3}{|c|}{ Ashworth Modified Scale Score } & \multicolumn{2}{|c|}{$\begin{array}{l}\text { Hoffman Reflex/Motor } \\
\text { Response (H/M) Ratio }\end{array}$} \\
\hline & & & & & & Before & $\begin{array}{l}\text { Immedi- } \\
\text { ately After }\end{array}$ & $\begin{array}{l}3 \text { Months } \\
\text { After }\end{array}$ & Before & $\begin{array}{c}\text { Immediately } \\
\text { After }\end{array}$ \\
\hline $\begin{array}{l}\text { Manganotti } \\
\text { et al. } \\
2005 \\
\text { [25] }\end{array}$ & Stroke/20 & $\begin{array}{c}\text { 1500/forearm } \\
\text { flexor mus- } \\
\text { cles, 3200/ } \\
\text { fingertips }\end{array}$ & $\begin{array}{l}\text { An active shockwave } \\
\text { session } \\
\text { All patients received } \\
\text { a placebo shock } 1 \\
\text { week before active } \\
\text { treatment. }\end{array}$ & 13 & 0.030 & $\begin{array}{l}3.04 \pm 0.7 \\
3.2 \pm 0.6\end{array}$ & $\begin{array}{l}2.0 \pm 0.9 \\
0.8 \pm 0.4\end{array}$ & $\begin{array}{l}3.0 \pm 0.5 \\
1.8 \pm 0.7\end{array}$ & & \\
\hline $\begin{array}{l}\text { Bae et al. } \\
\quad[37]\end{array}$ & Stroke/32 & $\begin{array}{l}\text { 1200/Biceps } \\
\text { muscle }\end{array}$ & $\begin{array}{c}\text { One session per } \\
\text { week and a total of } 3 \\
\text { sessions }\end{array}$ & 15 & 0.12 & $3.3 \pm 0.49$ & $1.8 \pm 0.38$ & $2.8 \pm 0.57$ & & \\
\hline
\end{tabular}

\begin{tabular}{|c|c|c|c|c|c|c|c|c|c|}
\hline $\begin{array}{l}\text { Amelio et } \\
\text { al. } 2010 \\
{[26]}\end{array}$ & $\begin{array}{l}\text { Cerebral } \\
\text { palsy/12 }\end{array}$ & $\begin{array}{l}\text { 1500/Gastro- } \\
\text { solius muscle }\end{array}$ & $\begin{array}{l}\text { One placebo treat- } \\
\text { ment session and } \\
\text { after } 6 \text { weeks, one } \\
\text { active shock wave } \\
\text { treatment session }\end{array}$ & 10 & 0.1 & $2.67 \pm 1.15$ & $1.22 \pm 1.03$ & $2.98 \pm 5.63$ & $3.12 \pm 5.78$ \\
\hline $\begin{array}{r}\text { Sohn et al. } \\
2011[33]\end{array}$ & Stroke/10 & $\begin{array}{l}\text { 1500/Gas- } \\
\text { trocnemius }\end{array}$ & $\begin{array}{l}\text { One shockwave } \\
\text { treatment session on } \\
\text { the inner head of the } \\
\text { gastrocnemius }\end{array}$ & 13 & 0.89 & $2.5 \pm 0.67$ & $1.41 \pm 0.67$ & & \\
\hline $\begin{array}{c}\text { Moon et al. } \\
2013 \\
{[24]}\end{array}$ & Stroke/30 & $\begin{array}{l}\text { 1500/Gas- } \\
\text { trocnemius }\end{array}$ & $\begin{array}{l}\text { One session of pla- } \\
\text { cebo treatment and } \\
\text { then, } 3 \text { sessions of } \\
\text { shockwave treatment } \\
\text { (1 session per week) } \\
\text { on the junction of } \\
\text { internal and external } \\
\text { gastrocnemius } \\
\text { muscle }\end{array}$ & 14 & 0.1 & $3.5 \pm 1$ & $2.1 \pm 1.1$ & & \\
\hline $\begin{array}{c}\text { Santamato } \\
\text { et al. } 2014 \\
{[38]}\end{array}$ & Stroke/23 & $\begin{array}{l}1500 / G a s t r o- \\
\text { solius muscle }\end{array}$ & $\begin{array}{c}\text { An active shockwave } \\
\text { session }\end{array}$ & 13 & 0.23 & $3.4 \pm 0.4$ & $2.1 \pm 0.6$ & & \\
\hline $\begin{array}{c}\text { Fouda et al. } \\
\qquad \begin{array}{c}2015 \\
{[39]}\end{array}\end{array}$ & Stroke/30 & $\begin{array}{l}\text { 1500/Hand } \\
\text { and finger } \\
\text { flexors, 3200/ } \\
\text { Intrinsic hand }\end{array}$ & $\begin{array}{l}\text { Patients were ran- } \\
\text { domly and equally } \\
\text { divided into two } \\
\text { groups. The first } \\
\text { group received the } \\
\text { usual physiotherapy } \\
\text { treatments with } \\
\text { placebo shockwave } \\
\text { therapy and the sec- } \\
\text { ond group received } \\
\text { the usual physiother- } \\
\text { apy treatments with } \\
\text { active shockwave } \\
\text { therapy (one ses- } \\
\text { sion per week for } 5 \\
\text { weeks). }\end{array}$ & 17 & 0.32 & & & & \\
\hline
\end{tabular}




\begin{tabular}{|c|c|c|c|c|c|c|c|c|c|c|}
\hline \multirow{3}{*}{$\begin{array}{l}\text { Author/ } \\
\text { Year of } \\
\text { Publication }\end{array}$} & \multirow{3}{*}{$\begin{array}{c}\text { Type of } \\
\text { Disease/ } \\
\text { Number of } \\
\text { Patients }\end{array}$} & \multirow{3}{*}{$\begin{array}{c}\text { Treatment } \\
\text { Dose (Num- } \\
\text { ber of Shots)/ } \\
\text { Treated } \\
\text { Muscles }\end{array}$} & \multirow{3}{*}{$\begin{array}{l}\text { Number of Treat- } \\
\text { ment Sessions/Treat- } \\
\text { ment Methods }\end{array}$} & \multirow{3}{*}{$\begin{array}{l}\text { Article } \\
\text { Quality } \\
\text { Score }\end{array}$} & \multirow{3}{*}{$\begin{array}{c}\text { Applied } \\
\text { Energy } \\
\left(\mathrm{mJ} / \mathrm{mm}^{2}\right)\end{array}$} & \multicolumn{5}{|c|}{ Mean \pm SD } \\
\hline & & & & & & \multicolumn{3}{|c|}{ Ashworth Modified Scale Score } & \multicolumn{2}{|c|}{$\begin{array}{l}\text { Hoffman Reflex/Motor } \\
\text { Response (H/M) Ratio }\end{array}$} \\
\hline & & & & & & Before & $\begin{array}{l}\text { Immedi- } \\
\text { ately After }\end{array}$ & $\begin{array}{l}3 \text { Months } \\
\text { After }\end{array}$ & Before & $\begin{array}{l}\text { Immediately } \\
\text { After }\end{array}$ \\
\hline $\begin{array}{l}\text { Gawad et } \\
\text { al. 2015 } \\
\text { [34] }\end{array}$ & $\begin{array}{l}\text { Cerebral } \\
\text { palsy/30 }\end{array}$ & $\begin{array}{l}700 / \text { Gastroc- } \\
\text { nemius and } s \\
\text { soleus }\end{array}$ & $\begin{array}{c}3 \text { sessions of active } \\
\text { shockwave treatment } \\
\text { during a week }\end{array}$ & 17 & & & & & $3.75 \pm 1.08$ & $1.95 \pm 0.06$ \\
\hline $\begin{array}{l}\text { Marinelli et } \\
\text { al. 2015 } \\
\text { [35] }\end{array}$ & $\begin{array}{l}\text { Multiple } \\
\text { Sclerosis/68 }\end{array}$ & $\begin{array}{c}2000 / \text { Gastro- } \\
\text { solius }\end{array}$ & $\begin{array}{l}\text { Patients were di- } \\
\text { vided into two equal } \\
\text { groups: treatment } \\
\text { group: four sessions } \\
\text { of treatment once } \\
\text { a week, and control } \\
\text { group: placebo treat- } \\
\text { ment }\end{array}$ & 22 & $\begin{array}{l}\text { Not men- } \\
\text { tioned }\end{array}$ & & & & $0.5 \pm 0.26$ & $0.56 \pm 0.24$ \\
\hline $\begin{array}{c}\text { Radinmehr } \\
\text { et al. 2016 } \\
\text { [32] }\end{array}$ & Stroke/12 & $\begin{array}{l}\text { 1500/Inner } \\
\text { gastrosolius }\end{array}$ & $\begin{array}{c}\text { An active shockwave } \\
\text { treatment session } \\
\text { on plantar flexor } \\
\text { muscles }\end{array}$ & 17 & 0.1 & & & & $0.45 \pm 0.25$ & $0.4 \pm 0.25$ \\
\hline $\begin{array}{l}\text { Wang et al. } \\
\qquad \begin{array}{c}2016 \\
{[23]}\end{array}\end{array}$ & $\begin{array}{c}\text { Cerebral } \\
\text { palsy/34 } \\
\text { Control } \\
\text { group/32 }\end{array}$ & $\begin{array}{l}1500 / \text { Gas- } \\
\text { trocnemius }\end{array}$ & $\begin{array}{l}\text { One active shock- } \\
\text { wave treatment } \\
\text { session per week for } \\
\text { three months }\end{array}$ & 27 & 0.30 & $\begin{array}{l}1.9 \pm 0.6 \\
\text { Right } \\
2.6 \pm 1 \\
\text { Left }\end{array}$ & $\begin{array}{l}1.2 \pm 0.7 \\
\text { Right } \\
1.9 \pm 1 \\
\text { Left }\end{array}$ & & & \\
\hline $\begin{array}{l}\text { Dymarek et } \\
\text { al. 2016 } \\
\text { [40] }\end{array}$ & Stroke/20 & $\begin{array}{l}\text { 1500/Wrist } \\
\text { flexors, carpal } \\
\text { flexor ulnaris } \\
\text { and radialis }\end{array}$ & $\begin{array}{l}\text { An active shock wave } \\
\text { treatment session }\end{array}$ & 19 & 0.30 & $2.1 \pm 0.9$ & $1.5 \pm 0.8$ & & & \\
\hline $\begin{array}{l}\text { Li et al. } \\
2016 \\
{[27]}\end{array}$ & Stroke/60 & $\begin{array}{l}\text { 4000/Intrinsic } \\
\text { muscles of } \\
\text { the hand }\end{array}$ & $\begin{array}{l}\text { Patients were ran- } \\
\text { domly divided into } \\
\text { three groups. The } \\
\text { first group received } \\
\text { one active shock- } \\
\text { wave session per } \\
\text { week for } 3 \text { consecu- } \\
\text { tive weeks. The sec- } \\
\text { ond group received } \\
\text { only one shockwave } \\
\text { treatment session } \\
\text { and the third group } \\
\text { received } 1 \text { placebo } \\
\text { shock treatment } \\
\text { session per week for } \\
3 \text { weeks. }\end{array}$ & 17 & $\begin{array}{l}\text { Not men- } \\
\text { tioned }\end{array}$ & $\begin{array}{l}3.3 \pm 0.22 \\
\mathrm{Ga} \\
3.1 \pm 0.26 \\
\mathrm{~Gb}\end{array}$ & $\begin{array}{l}1.5 \pm 0.5 \\
\mathrm{Ga} \\
1.5 \pm 0.15 \\
\mathrm{~Gb}\end{array}$ & $\begin{array}{c}1.9 \pm 0.5 \\
\mathrm{Ga} \\
2.24 \pm 0.8 \\
\mathrm{~Gb}\end{array}$ & & \\
\hline $\begin{array}{l}\text { Lee et al. } \\
2019 \\
{[19]}\end{array}$ & $\begin{array}{l}\text { Stroke/9 } \\
\text { Control } \\
\text { group/9 }\end{array}$ & $\begin{array}{l}\text { 2000/Gas- } \\
\text { trocnemius }\end{array}$ & $\begin{array}{l}\text { Patients were } \\
\text { divided into two } \\
\text { equal groups: the } \\
\text { treatment group } \\
\text { received one active } \\
\text { shockwave treatment } \\
\text { session and the con- } \\
\text { trol group received } \\
\text { placebo treatment. }\end{array}$ & 20 & 0.1 & $2.2 \pm 1.09$ & $0.1 \pm 78.89$ & & & \\
\hline
\end{tabular}

Archives of

confidence interval. $\left[\mathrm{I}^{2}=100 \% ; \mathrm{P}<0.001, \mathrm{SDM}=1.38\right.$ With 95\% CI: $(0.80,1.87)]$. Figure 2 of the Forest Plot diagram shows the extent of changes in the Ashworth scale before and immediately after SWT in general and separately for all studies. With a confidence interval of $95 \%$, the difference between the mean before and immediately after the Ashworth scale was equal to 0.80 and 1.87 , respectively, which 


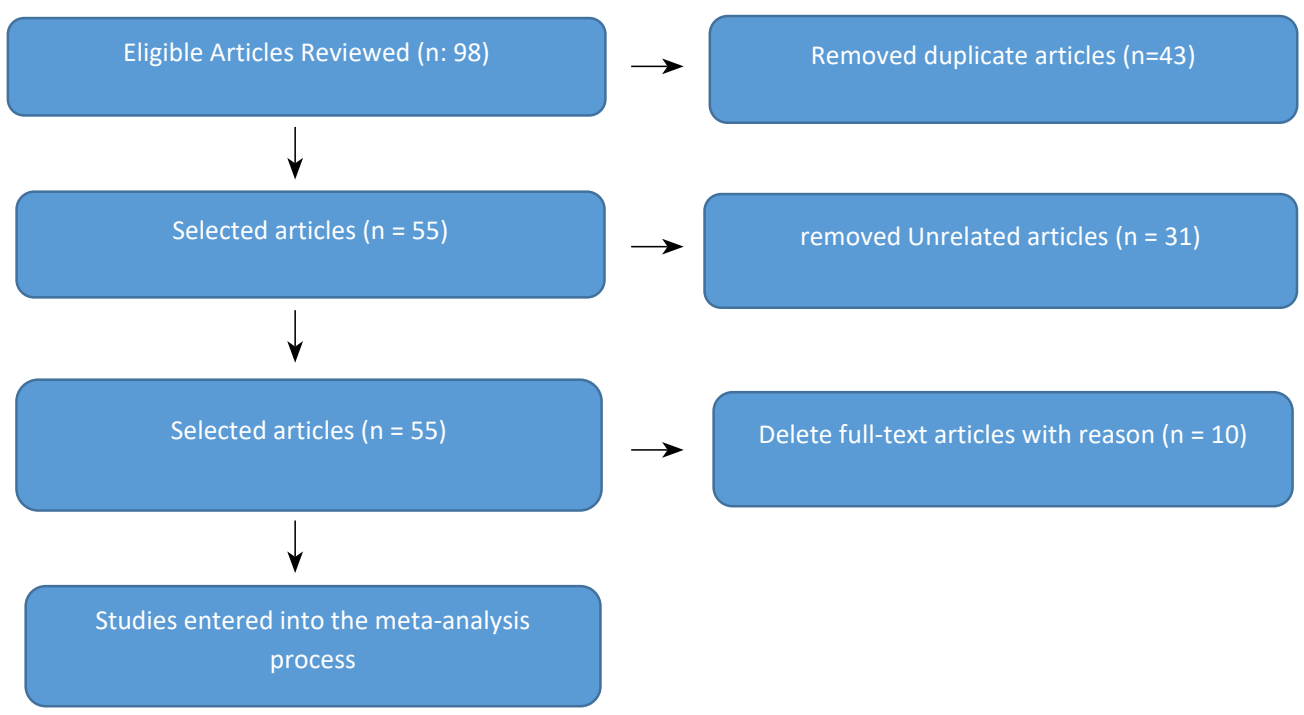

Figure 1. Flowchart of the steps for study selection in a systematic review and meta-analysis

shows that the mean of the Ashworth scale before and immediately after the intervention was significantly different.

The results of the meta-analysis also showed that three months after the intervention, the scores of the MAS decreased significantly. $\left[\mathrm{I}^{2}=100 \%, \mathrm{p}<0.001, \mathrm{SMD}=1.13\right.$ with $95 \% \mathrm{CI}:(0.50,1.76)]$. Figure 3 of the Forest Plot diagram shows the rate of changes in the scale of Ashworth scale before and 3 months after SWT in general and separately for all studies

With a $95 \%$ confidence interval, the mean difference in comparison between before and 3 months after the Ash- worth Scale was equal to 0.50 and 1.76 , respectively, which shows that the mean Ashworth Scale before and 3 months after the intervention was significantly different.

B- Analyzing the results of studies included in the metaanalysis by examining the effect of shockwave on the Hoffman reflex/motor response $(\mathrm{H} / \mathrm{M})$ ratio:

Four studies with a total of 120 patients had evaluated the effects of SWT on the H/M ratio. Figure 4 shows the Forest plot diagram of changes in $\mathrm{H} / \mathrm{M}$ ratio before and after SWT in general and separately for all studies. With a 95\% confidence interval, the mean difference in comparison with

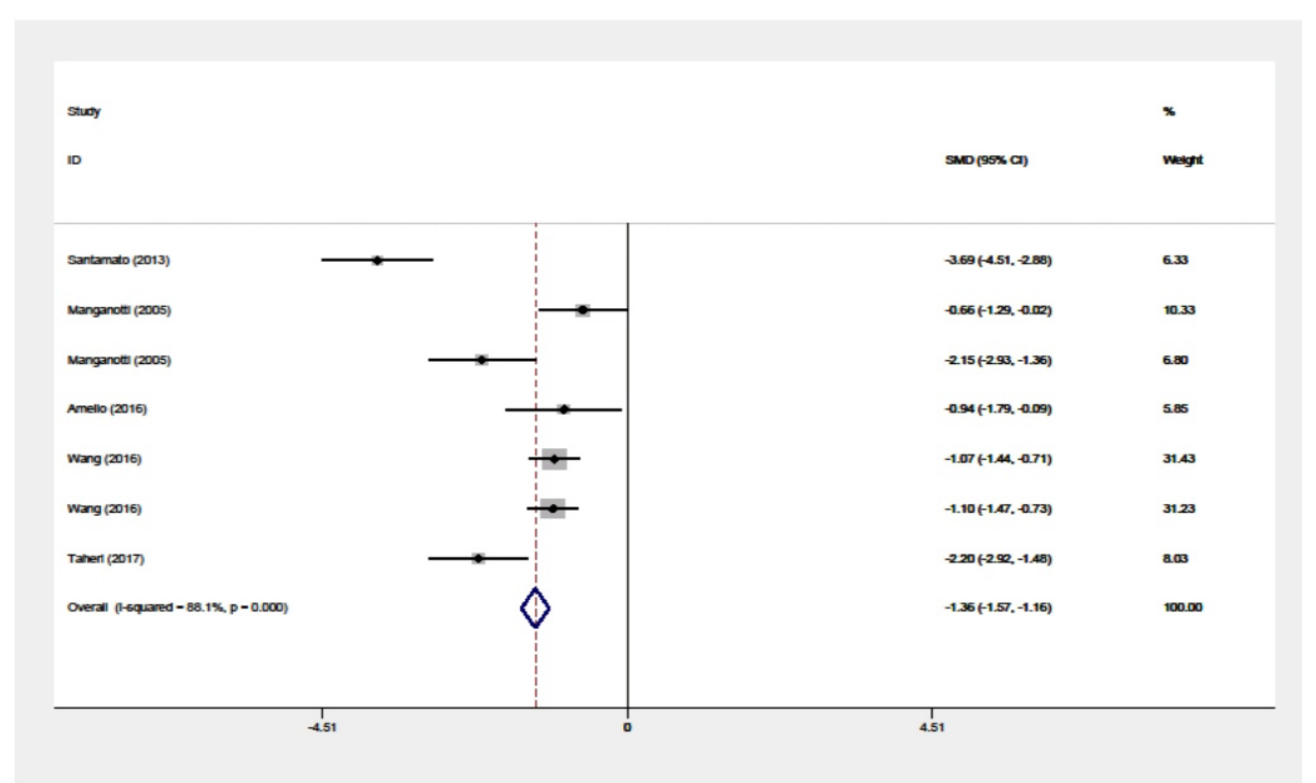

Archives of Rehabilitation

Figure 2. Forest plot diagram estimating the rate of decrease in Ashworth scale before and immediately after treatment 


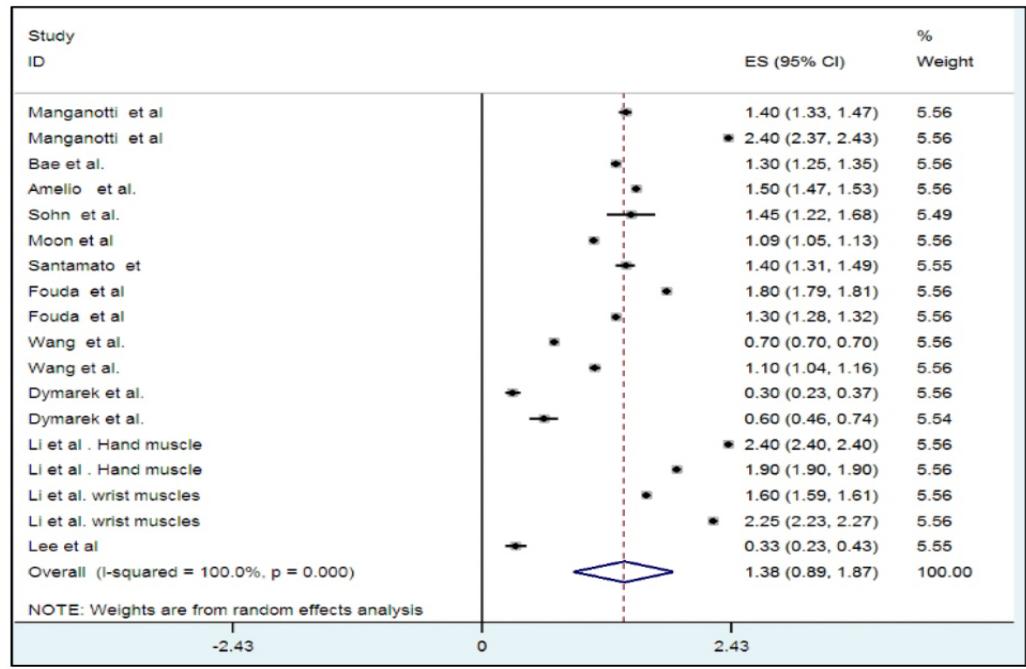

Rehabilitation

Figure 3. Forest plot diagram estimating the rate of Ashworth scale reduction compared with before and 3 months after treatment

before and after the ratio of $\mathrm{H} / \mathrm{M}$ was 0.54 and 2.73 , respectively, which indicates that the mean index of the H/M ratio before and after the intervention was not significantly different.

\section{Discussion and Conclusion}

In general, one of the most important goals of meta-analysis studies is to solve problems caused by controversial results of previous studies. In these studies, by combining several studies with specific characteristics, the sample size increases, which reduces the confidence interval of measurements. As a result, a valid result can be presented from previous studies [28].

The results of the present study showed that the degree of the Ashworth scale decreased significantly after shockwave application. In this meta-analysis, the effects of shockwave on the reduction of spasticity at follow-up (3 months after treatment) were also significant. So far, several systematic reviews and meta-analyses have been performed to evaluate the effect of SWT on spasticity in patients with upper motor neuron lesions. However, no study has been performed on the simultaneous evaluation of the effects of SWT on the clinical and neurophysiological symptoms of spasticity in patients with upper motor neuron lesions with different etiologies.

The results of other review studies that have examined the effect of SWT on the severity of spasticity are consistent with the results of the present study. Lee et al. (2014) reviewed 5 studies ( 3 studies in patients with partial paralysis and 2 studies in patients with cerebral palsy) and stated that the MAS score immediately and 4 weeks after SWT significantly improved compared with the baseline values [29].

Guo et al. (2017) in their systematic review and metaanalysis and based on data from 6 studies on stroke patients, analyzed the effects of SWT in reducing spasticity and reported significant differences between baseline values of the Ashworth scale immediately and 4 weeks after treatment [30].

Xiang et al. (2018) in their systematic review and metaanalysis of 8 clinical trials on stroke patients reported that there is a high level of evidence to confirm the positive effects of SWT in reducing spasticity immediately after treatment. Ashworth, Tardio scale, $\mathrm{H} / \mathrm{M}$ ratio, and joint range of motion were analyzed in this study [31].

A systematic review and meta-analysis conducted in 2020 by Cabanas-Valdés et al. obtained similar results to the results of the present study. In two separate articles, the author examined the effects of SWT on reducing spasticity of the lower and upper limb muscles in patients with partial paralysis and reported that SWT has significant effects on improving the MAS, range of motion, and Fugl Meyer criteria in the short and long term [10].

Another finding of this study showed was no significant changes in alpha motor neuronal excitability (H/M ratio) in patients with upper motor neuron lesions after SWT.

This finding contradicts the findings of a review study by Guo et al. [30]. A noteworthy point in their study was that the effects of SWT on H/M ratio were assessed only by meta-analysis of one study, while in the present study meta- 


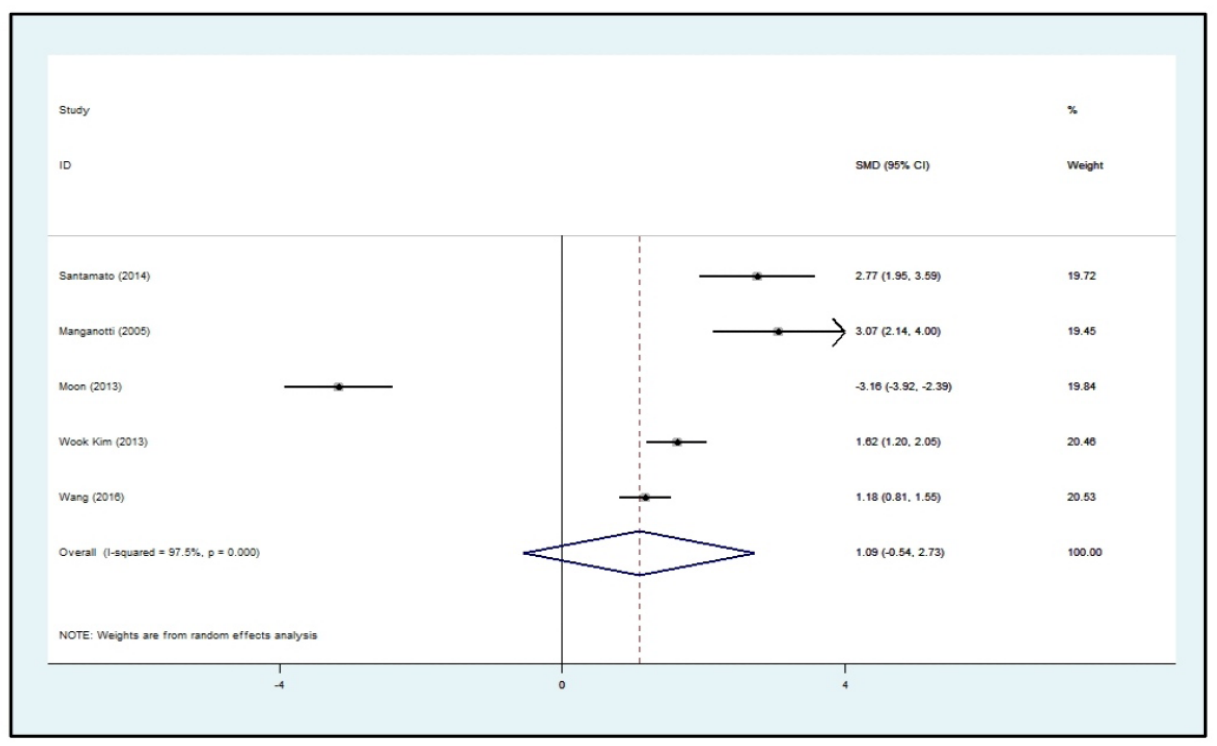

Figure 4. Forest plot diagram estimating the amount of $\mathrm{H} / \mathrm{M}$ Ratio changes before and immediately after treatment

analysis was performed according to the inclusion criteria of 4 articles. Therefore, this could be a justification for the discrepancy between the findings of the present study and their study.

In this context, based on inclusion criteria, four articles that had investigated the immediate effects of spastic muscle SWT on the H/M ratio were included in this study. Radinmehr et al. (2016) reported that by performing a shockwave session on the gastrocnemius muscle of 12 stroke patients and recording the $\mathrm{H} / \mathrm{M}$ ratio immediately and one hour after treatment, despite the reduction of the H-reflex latency, no change in the H/M ratio was observed [32]. Shon et al. (2011) in their study on 10 stroke patients reported that one session of SWT on the gastro-soleus muscle did not show significant changes in the $\mathrm{H} / \mathrm{M}$ ratio compared with before treatment [33]. Gawad et al. (2015), observed a significant decrease in the $\mathrm{H} / \mathrm{M}$ ratio after 3 sessions of treatment in patients with cerebral palsy [34]. Marinelli et al. (2015) reported that 4 sessions of SWT could significantly reduce electrophysiological parameters in patients with multiple sclerosis [35].

A significant consideration in studies that have examined the $\mathrm{H} / \mathrm{M}$ ratio of spasticity is the time interval between the onset of upper motor neuron lesions. However, the H/M ratio is a reliable measure of the excitability of upper motor neurons. However, studies using the $\mathrm{H} / \mathrm{M}$ ratio to assess spasticity did not indicate the onset of upper motor neuron lesi ons in patients with the disease. Hiersemenzel et al. (2000) reported that the H/M ratio reaches its maximum value at least 2 to 6 months after the onset of upper motor neuron lesion and then, remains constant [36]; thus, the H/M ratio may not be stable before this time. Therefore, it seems that the evaluation of patients in terms of the $\mathrm{H} / \mathrm{M}$ ratio concerning the time of onset of the complication is an important factor in the evaluation result and can affect the results of the study. Therefore, it is recommended that studies that use this ratio to evaluate the effects of different therapies on spasticity consider the time elapsed since the onset of upper motor neuron lesion. Although the results of all studies confirm the positive effects of SWT in reducing spasticity based on the Ashworth scale, it seems that many questions must be answered before this method can be recommended to patients as a common method of reducing spasticity.

First, to determine the independent effect of shockwave on spasticity, it is necessary to limit the use of any other treatment that can affect the severity of spasticity to avoid confusion in the expression of results. For example, Gawad et al. (2015) in their study used exercise therapy protocol in the control and treatment groups along with SWT [34]. Wang et al. (2016) used Chinese massage and electrical stimulation along with SWT [23]. Sohn et al. (2011) used antispasmodics with a shock wave in their study [33]. On the other hand, differences in the number of treatment ses sions, treatment session intervals, energy density and number of shocks applied, and follow-up time need to be examined more closely. The existence of these differences significantly increases the level of heterogeneity in studies. Therefore, because of the lack of adequate data from the main articles for meta-analysis of the above variables in any of the reviews and meta-analyses, the effect of SWT with different shocks and intensities and the duration of different treatments was not analyzed. Therefore, in future studies, it is recommended to conduct clinical trials considering the following items: 1. Patients should be divided into different groups based on the characteristics of the shock wave, the number of treatment sessions, and the duration of follow- 
up; 2. The samples should be matched in terms of the Ashworth scale; 3 . Factors related to spasticity (type of upper motor neuron lesion and even type of stroke) should also be considered in the selection of patients.

One of the limitations of this study is the small number of well-designed clinical trials, considering that the mechanism of effectiveness of SWT on spasticity is not yet fully understood, and on the other hand, there is no integrated protocol in the treatment of spasticity by SWT; thus, more trials with appropriate designs are needed in the future.

The results of this review study showed that SWT is a noninvasive method that can be easily used in spastic muscles of the lower and upper limbs in patients with upper motor neuron lesions and has beneficial effects on improving the clinical scale of spasticity assessment. Because there is still no single instruction for treating patients in terms of the number of treatment sessions, energy intensity, and several shocks applied, and on the other hand, none of the studies provided a documented reason for choosing the number of sessions and pulse intensity as a common method of reducing spasticity, conducting high-quality randomized clinical trials is suggested to analyze the factors affecting SWT on spasticity.

\section{Ethical Considerations}

Compliance with ethical guidelines

All ethical principles are considered in this article.

Funding

This article has been done with the financial support of the Vice Chancellor for Research and Technology of Shahid Beheshti University of Medical Sciences.

Authors' contributions

Conceptualization and project management: Nahid Tahan; Research: Nahid Tahan and Farideh Dehghan Manshadi; Data collection: Nahid Tahan and Fereshteh Poursaid; Editing and writing - review \& editing: All authors; Statistical analysis: Alireza Akbarzadeh Baghban.

\section{Conflict of interest}

The authors declared no conflict of interest.
The authors thank the Vice Chancellor for Research and Technology of Shahid Beheshti University of Medical Sciences. 
مقاله مرورىى:

ثأثير شاكويودرمانى بر شاخص هاى بالينى و نوروفيزيولوريك اسياستيسيتى در بيماران دارئي

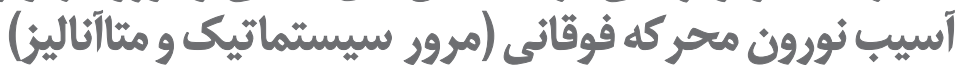

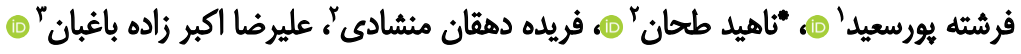 \\ 1. بروه فيزيوترإيى، دانشكده مطالعات حرفهاي، دانشعاه نورث ايسترن، بوستن، ماساجوست، ايلات متحده مامريكا.

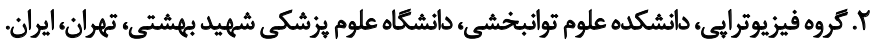

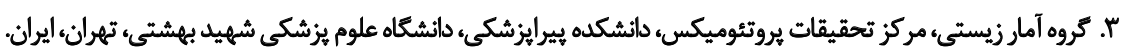

\begin{abstract}
حكיد

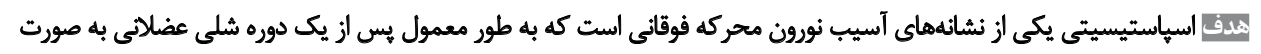

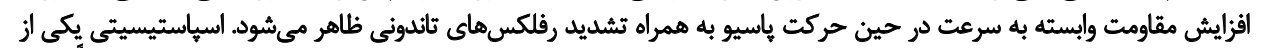

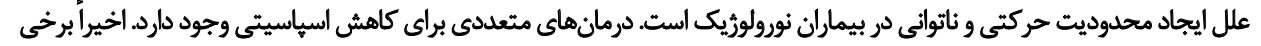

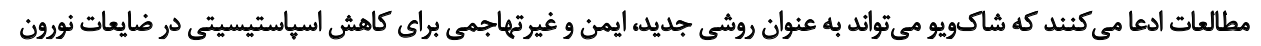

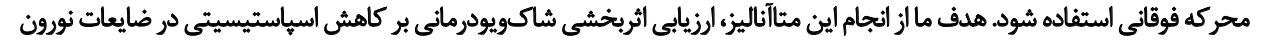
محركه فوقائى بود.

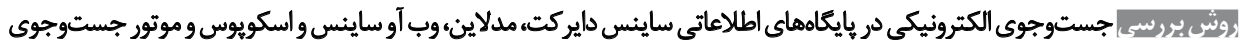

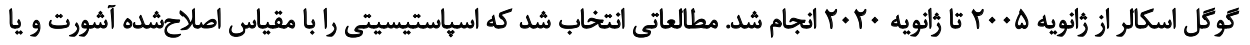

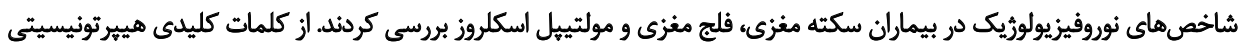

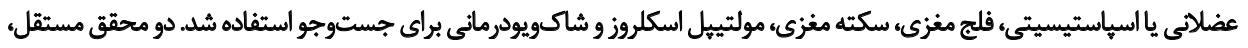

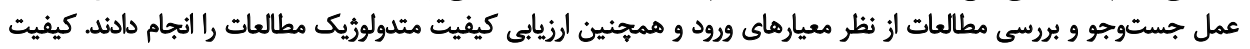

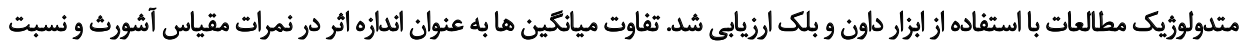

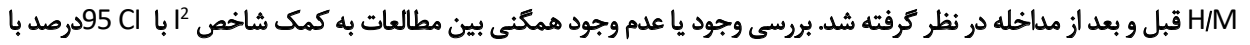

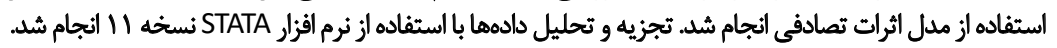

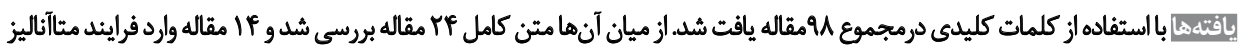

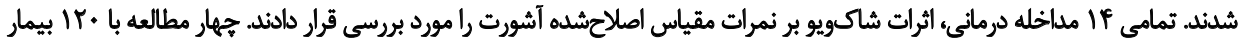

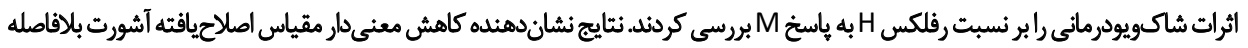

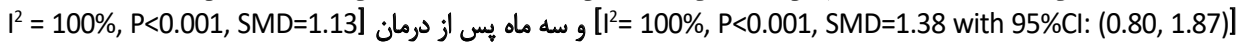

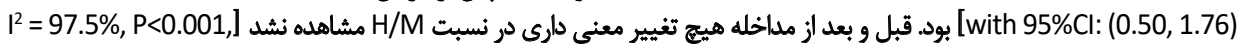

[SMD=1.09 with 95\%Cl: $(-0.54,2.73)$

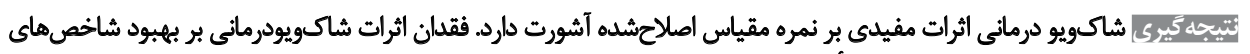

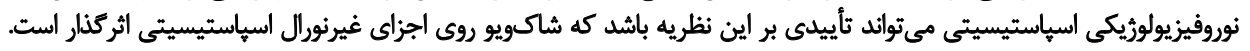

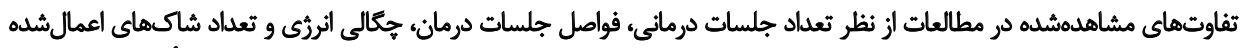

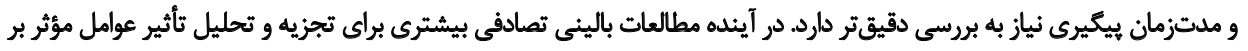
شاكويودرمانى براى بيمار ان اسياستيك مورد نياز است.
\end{abstract}

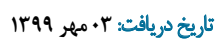

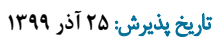


در سطح عضله قادر به تغيير در جريان حسى عضله است كه با بإيان مقدمه

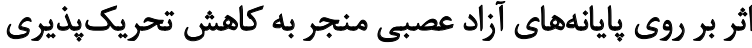

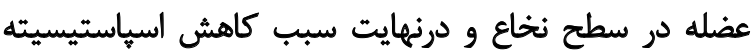

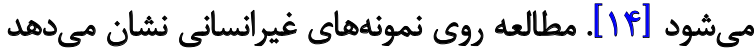

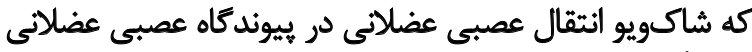

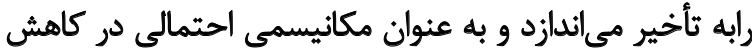

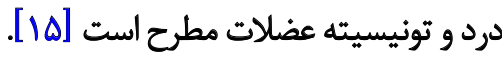

ابزارهاى بالينى و روشهاى نوروفيزيولوريك مختلفى

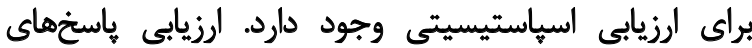

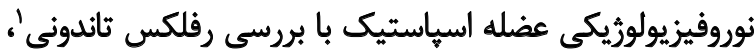

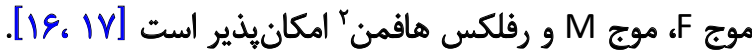

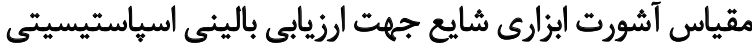

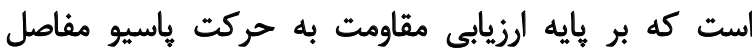

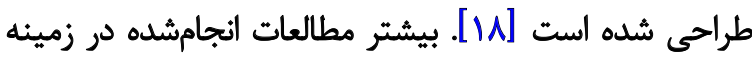
اثرات شاكويودرمانى بر تون عضلاتى ازي مقياس بالي بالينى آشورت

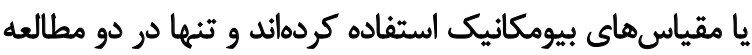

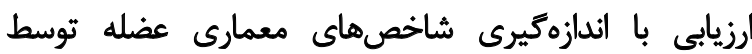

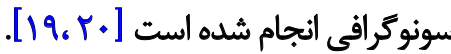

با توجه به ضرورت درمان اسياستيسيتى در بيماران نورولورثى

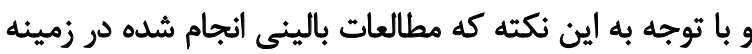

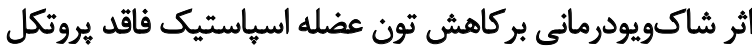

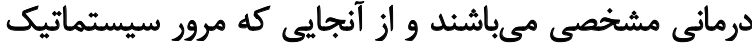

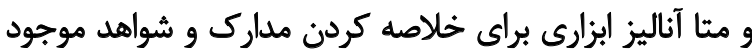

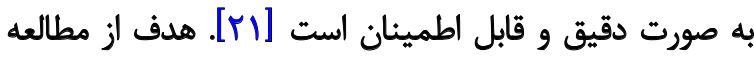

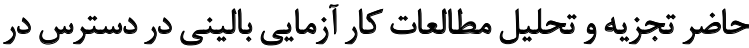

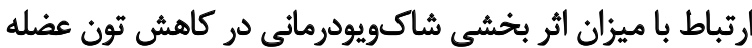

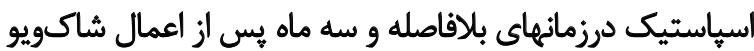
در بيماران ضايعه نورون محركه فوقانى مى باشاشد.

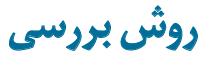

در اين مطالعه بانكهاي اطلاعاتى شامل ساينس دايركت،

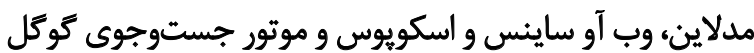

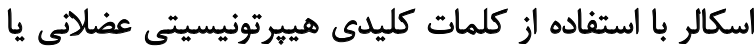

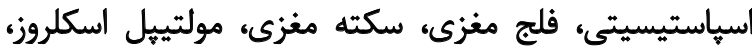

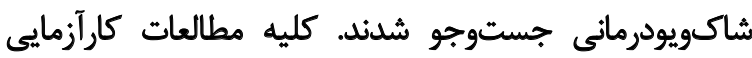

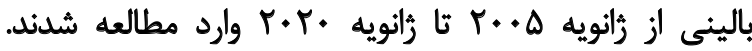

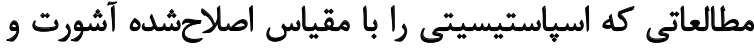

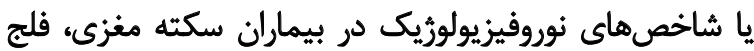

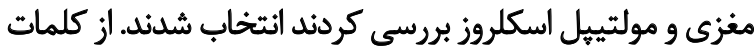

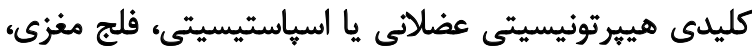
سكته مغزى، مولتييل اسكلروز و شاكويودرمانى براى جستوجي

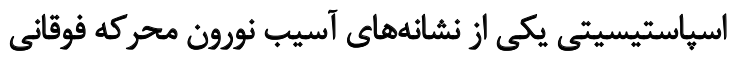

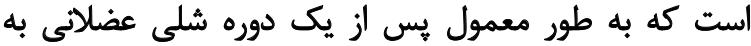

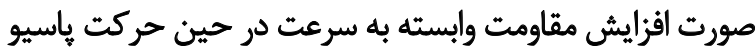

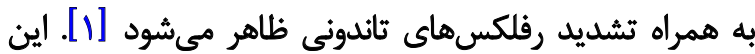

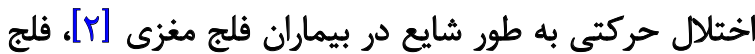

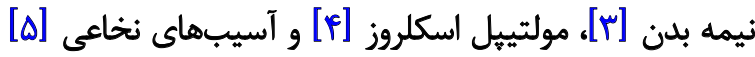

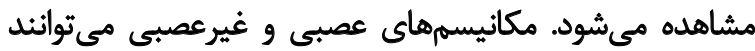

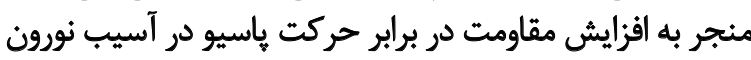

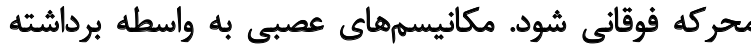

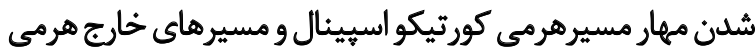

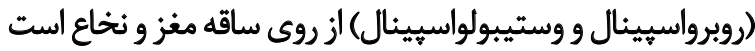

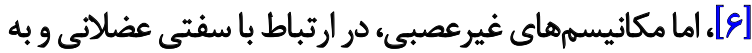

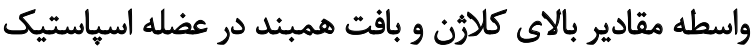

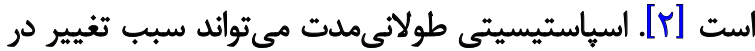
خواص ساختارى عضله دركير و عضلات مجاور به صورت كورت كوتاهي يا فيبروز عضلات شود كه سبب كنترل غير طبيعى موقعيت اندام

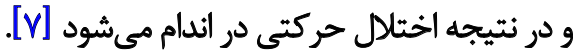

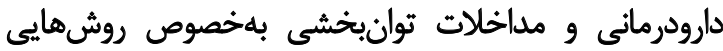

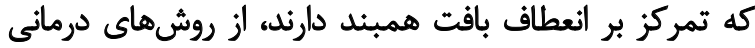

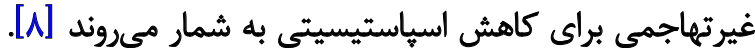

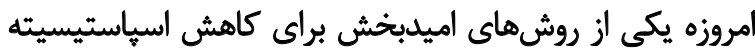

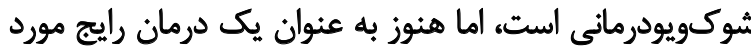

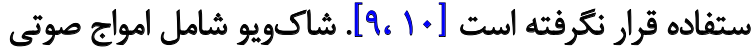

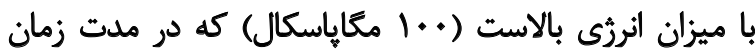

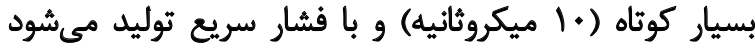

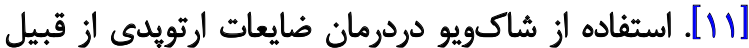

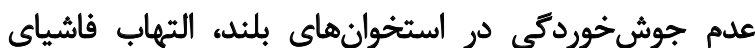

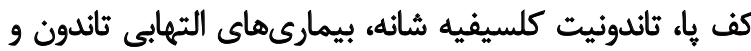

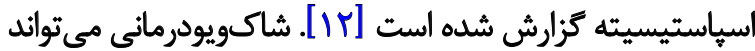

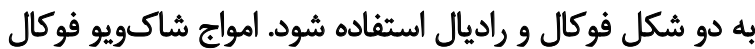

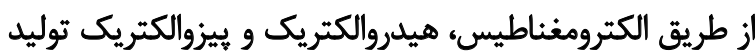

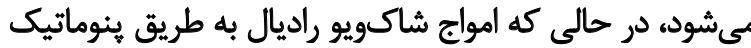

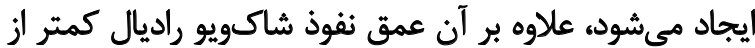

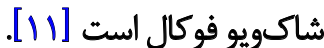

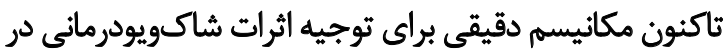

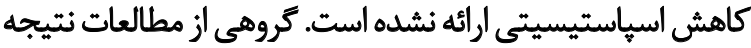

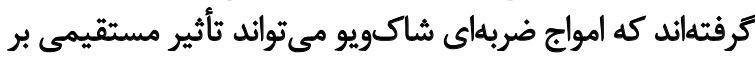

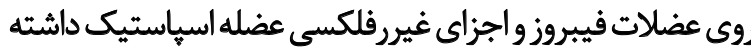

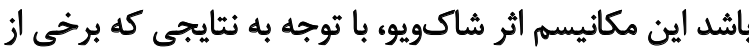

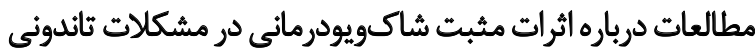

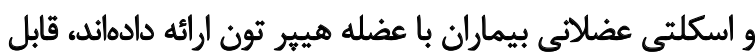

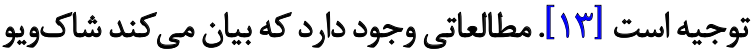




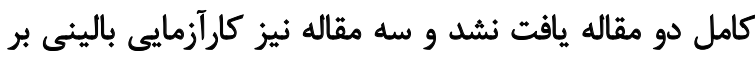

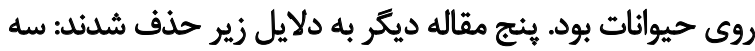

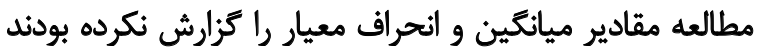

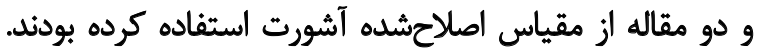

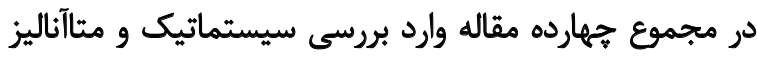

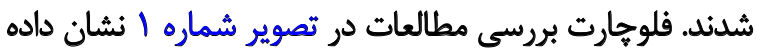

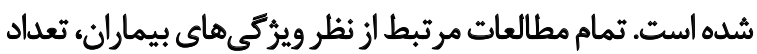

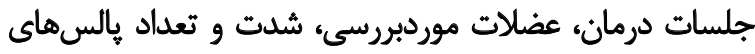

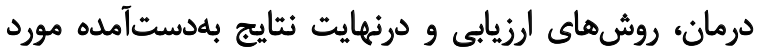

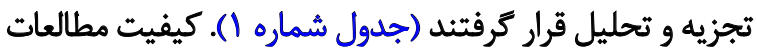

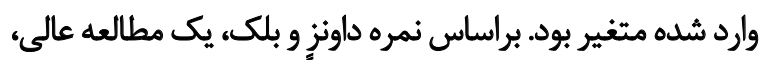

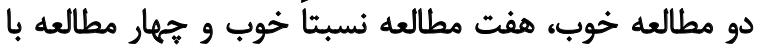

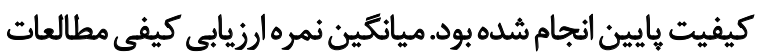

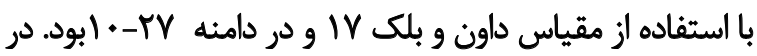
جدول شماره انمرات كيفى تمام مطالعات نشان داده شده است

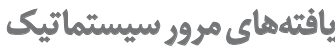

همانطور كه در جدول شماره آ آورده شده است، تفاوتهاى

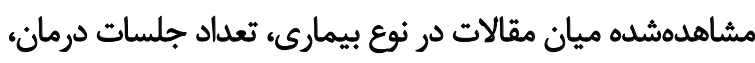
عضلات مورد بررسى و انررُى اعمالشهده است. از مجموع جهارده مقاله واردشده به مطالعه، يازده مقاله تأثير

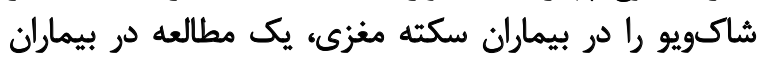

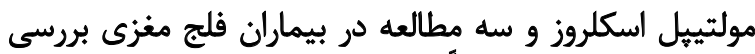

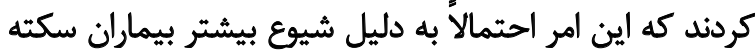

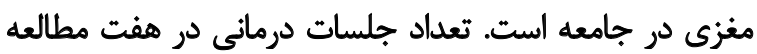

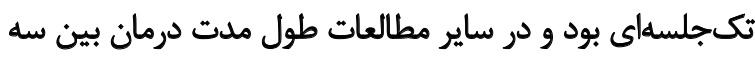

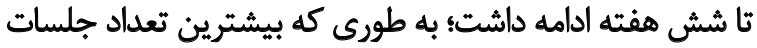

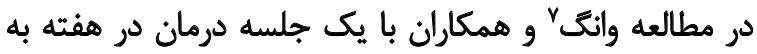

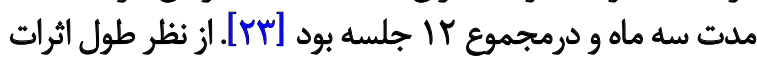

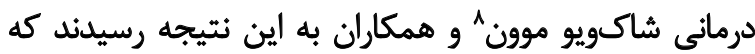

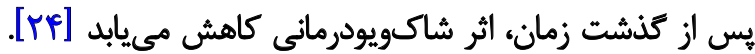

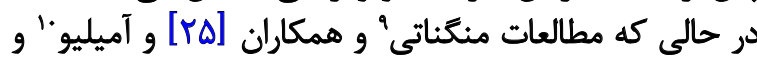

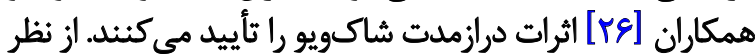

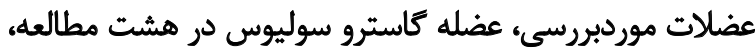

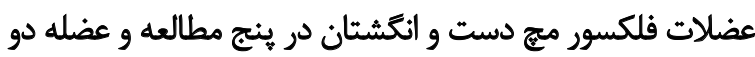

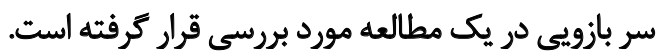

تفاوت دريارامترهاى دستكاه شوك ويو از نظر شدت انترزى

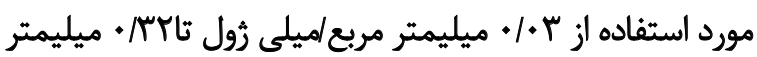

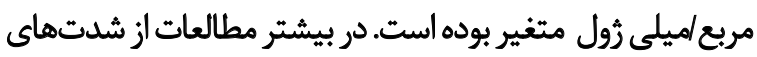

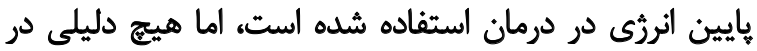

\footnotetext{
7. Wang

8. Moon

9. Manganotti

10. Amelio
}

استفاده شد. جستوجو و بررسى مطالعات واجد شرايط از نظر

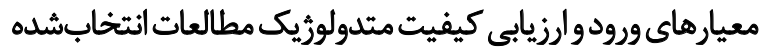
توسط دو محقق مستقل انجام شد.

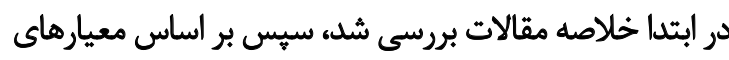

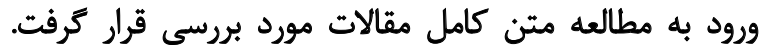

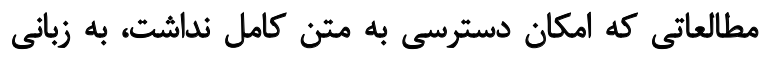

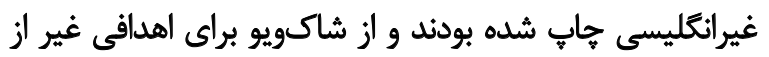

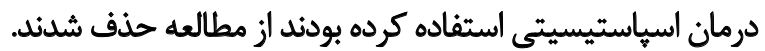

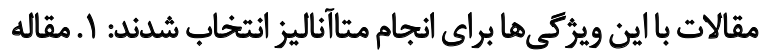

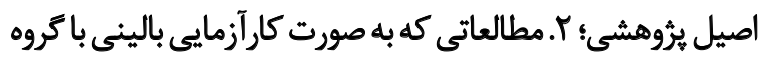

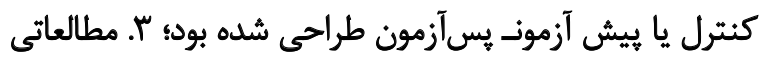

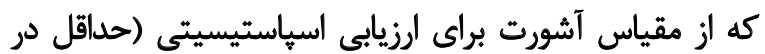

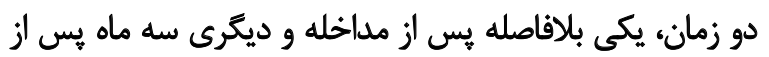

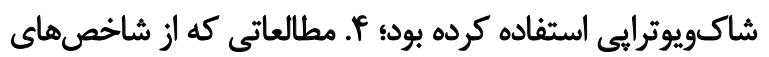

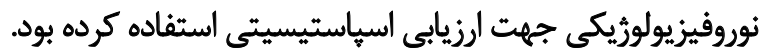

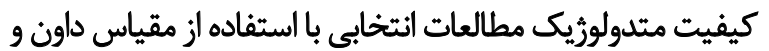

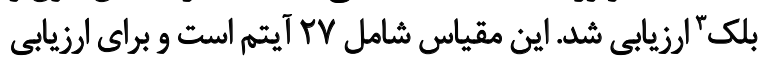

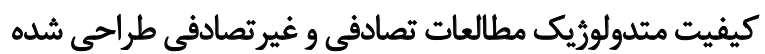

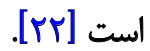

$$
\text { آناليز آمارى }
$$

تفاوت ميانكينها به عنوان اندازه اثر "در نمرات مقياس آشورت

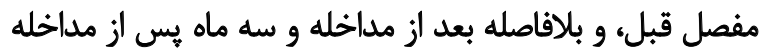

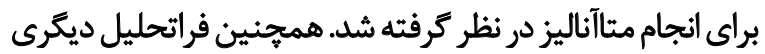

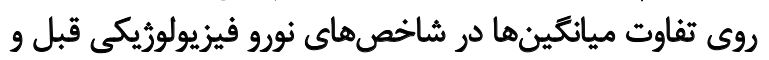

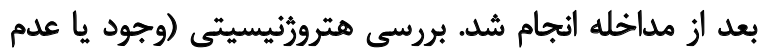

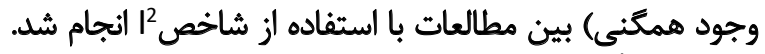

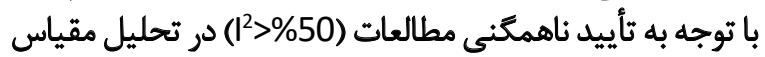

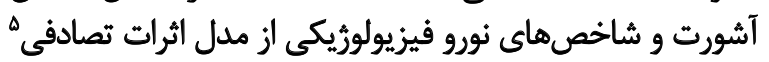

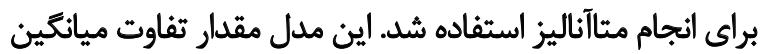

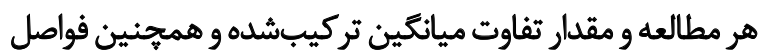

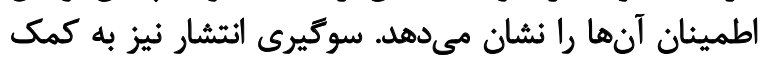

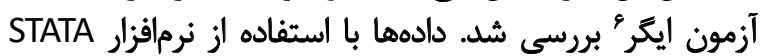

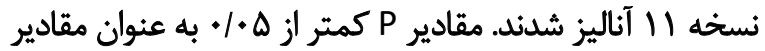
معنى دار از نظر آمارى در نظر كرفته شدند آنداليز

ياقتهاه

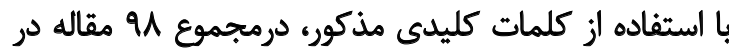

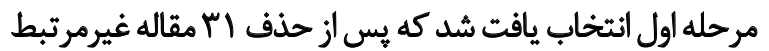

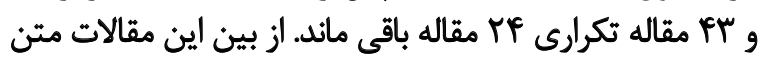

\footnotetext{
3. Downs and Black score

4. Effect size

5. Random effects model

6. Egger's test
} 
جدول ا. مطالعات مرتبط با كاربرد شاكويو براي كاهش اسياستيسيتى در بيماران با ضايعه نورولوزيكى

\begin{tabular}{|c|c|c|c|c|c|c|c|c|c|c|}
\hline \multicolumn{5}{|c|}{ مياثكين+اتحرافمعيار } & \multirow{3}{*}{$\begin{array}{c}\text { اعمالرشده } \\
\text { (mJ/ } \\
\left.\text { mm²) }^{2}\right)\end{array}$} & \multirow{3}{*}{ كيفيت } & \multirow{3}{*}{ ترمان/ زورشات } & \multirow{3}{*}{ (تعداد شرات) / عضات } & \multirow{3}{*}{ توعاد بيماري / } & \multirow{3}{*}{ سال انتشار } \\
\hline \multicolumn{2}{|c|}{ نسبت H/M } & \multicolumn{3}{|c|}{ ثمره مقياس اصلاحشده آشورت } & & & & & & \\
\hline بالافاصله & قرمان از & سر از ماه & 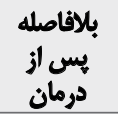 & قرمان & & & & & & \\
\hline & & $\begin{array}{l}r / \cdot \pm \cdot / \Delta \\
1 / A \pm \cdot / V\end{array}$ & $\begin{array}{l}r / \bullet \pm \cdot / q \\
\cdot / A \pm \cdot / f\end{array}$ & $\begin{array}{l}r /+4 \pm \cdot / V \\
r / T \pm \cdot / 8\end{array}$ &.$\%$ & Ir & 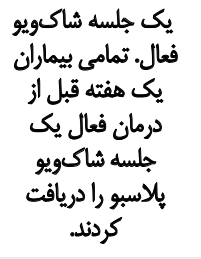 & 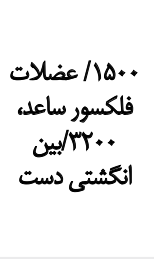 & سكته مغزى/r r & 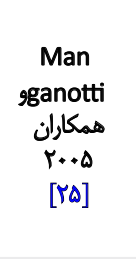 \\
\hline & & & $\pm V / 1 \Delta$ & $r / q \pm+/ \Gamma$ &.$/ \mathrm{r}$ & 10 & ودر كل سلسه در هلسنه & 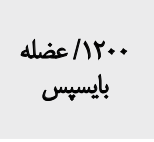 & سكته مثزى/T/ & 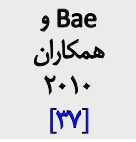 \\
\hline & & $r / A \pm \cdot / \Delta Y$ & $V / \Lambda \pm+/{ }^{\prime} \lambda$ & $r / \pi \pm \cdot / F q$ & $.1+\%$ & IV & 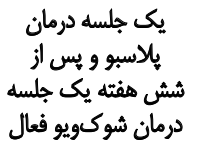 & كاستروسوليولهضله & فلج مغزى/W & $\begin{array}{l}\text { Amelio } \\
\text { g همكاران } \\
Y=1 . \\
{[r e]}\end{array}$ \\
\hline$r / M \pm \Delta / N$ & $\mathrm{r} / \mathrm{M} \pm / R$ & & $V / r M \pm V /+r$ & $r / Q V \pm 1 / 1 \Delta$ &.$n$ & 1. & 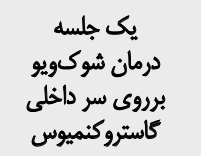 & كاستروكنميوس $10 .$. & سكته منزى|+1 & 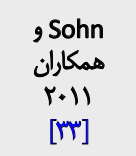 \\
\hline & & & $\mid / P I \pm \cdot / E V$ & $r / \Delta \pm \cdot / \& V$ & $1+19$ & r & 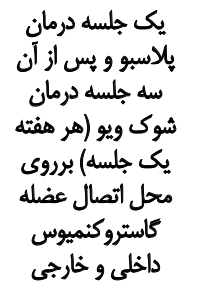 & كاستروكثميوس & سكته مغزى / r r & 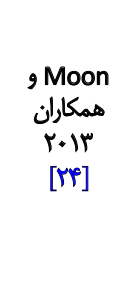 \\
\hline & & & $r / \triangle \pm V / /$ & $r / \Delta \pm 1$ &.$/ 1$ & if & يك جلسه شاكسويو & كاستروسوليوس & سكته مغزى/T & $\begin{array}{c}\text { Santamato } \\
\text { وهماران } \\
r+1 \% \\
{[\mathrm{rA}]}\end{array}$ \\
\hline & & & $r / \Delta \pm \cdot / \&$ & $r / \epsilon_{ \pm \bullet / F}$ & . & ז & 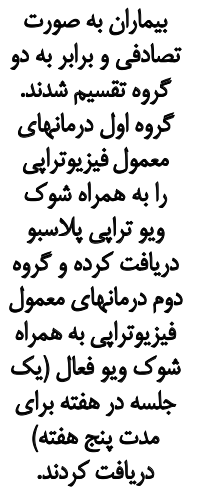 & 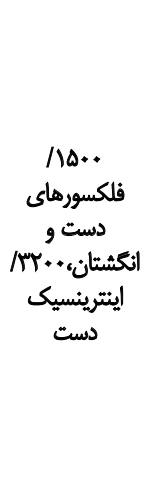 & 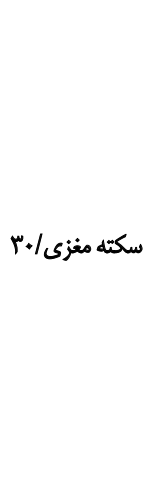 & $\begin{array}{c}\text { g Fouda } \\
i \text { هماران } \\
r+10 \\
{[r q]}\end{array}$ \\
\hline $1 / 9 \Delta \pm .1 .8$ & $r / N A \pm \cdot / A$ & & & &.$/ m$ & iv & 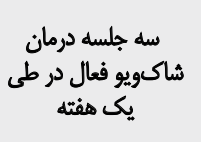 & كاستروكنميوس & فلج مغزى/.r & $\begin{array}{c}\text { Gawad } \\
\text { و } \\
\text { Y.lo } \\
{[M r]}\end{array}$ \\
\hline
\end{tabular}




\begin{tabular}{|c|c|c|c|c|c|c|c|c|c|c|}
\hline \multicolumn{5}{|c|}{ مياتثين土|تحرافمعيار } & \multirow{3}{*}{ 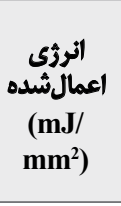 } & \multirow{3}{*}{ كيفيت } & \multirow{3}{*}{ تعرمان/ جلسات دوش } & \multirow{3}{*}{ (تعداد شُاتات) } & \multirow{3}{*}{ تعداد بيماران / نوان } & \multirow{3}{*}{ سال انتشار } \\
\hline \multicolumn{2}{|c|}{ نسبت H/M } & \multicolumn{3}{|c|}{ نمره مقياس اصلاحشده آشورت } & & & & & & \\
\hline 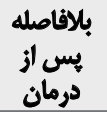 & قرمبل از & سه ماه & بإناصله & قرمان از & & & & & & \\
\hline$\cdot / \varphi \pm \cdot / r \Delta$ & $\cdot / \Delta \pm \cdot / R$ & & & & اشاره نشده & r & 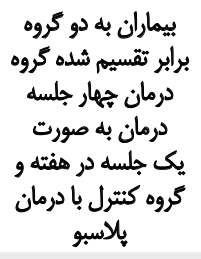 & كاستروسوليوس +.... & اسكلروزيتيل & $\begin{array}{c}\text { Marinelli } \\
\text { g هoه g } \\
r+10 \\
{[r \Delta]}\end{array}$ \\
\hline \multirow[t]{6}{*}{$+/ F \pm+/ T \Delta$} & $+/ F \Delta \pm+/ T \Delta$ & & & & $+/ 1$ & iv & 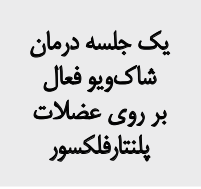 & كاستروسوليوس داخلى & 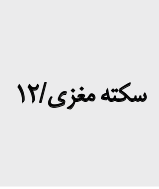 & $\begin{array}{l}\text { Radin- } \\
\text { gmehr } \\
\text { همكاران } \\
r \cdot 1 \& \\
{[r Y]}\end{array}$ \\
\hline & & & 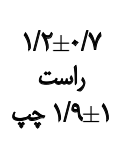 & 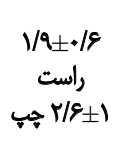 &.$/ \%$ & iv & 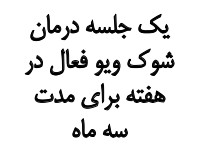 & كاستروكنميوس & فلج مغزي/" & $\begin{array}{c}\text { gWang } \\
\text { Wha } \\
r+18 \\
{[\pi+r]}\end{array}$ \\
\hline & & & $1 / \Delta \pm \cdot / 1$ & $r / M \pm \cdot / q$ &.$/ \%$ & 19 & شيك جلسه درمان & 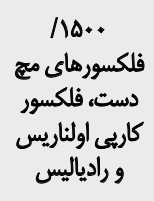 & سكته مغزى r r r & 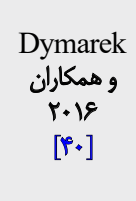 \\
\hline & & $\begin{array}{c}1 / q \pm \cdot / \Delta \\
G a \\
r / M r_{ \pm \cdot / A} \\
G b\end{array}$ & $\begin{array}{c}1 / \cdot \Delta \pm \cdot / \Delta \\
\mathrm{Ga} \\
1 / \Delta \pm \cdot / 1 \Delta \\
\mathrm{Gb}\end{array}$ & $\begin{array}{c}r / \% \pm \cdot / r \\
\mathrm{Ga} \\
r / / \pm \cdot / r q \\
\mathrm{~Gb}\end{array}$ & اشاره نشده & iv & 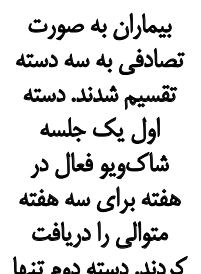 & اينترينسيك عضلات & سكته مغزى /8 & $\begin{array}{c}\text { g gi } \\
Y+18 \\
{[T Y]}\end{array}$ \\
\hline & & $\begin{array}{l}W / N \Delta \pm V / F \\
G a \\
T / q \pm \cdot / / F \\
G b\end{array}$ & $\begin{array}{c}\cdot / \Delta \pm \bullet / 1 \\
\mathrm{Ga} \\
\mathrm{I} / \mathrm{r} \pm \bullet / / r \\
\mathrm{~Gb}\end{array}$ & $\begin{array}{c}r / q \pm V / q \\
\mathrm{Ga} \\
r / / \pm \bullet / q q \\
\mathrm{~Gb}\end{array}$ & اشاره نشده & iv & 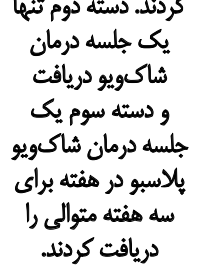 & كاريي اولثلاريس & سكته مغزى /4 & $\begin{array}{c}\dot{i}, \mathrm{Li} \\
r \cdot 18 \\
{[\mathrm{TV}]}\end{array}$ \\
\hline & & & $\cdot / \mathrm{N} \pm \mathrm{V} / \wedge q$ & $r / r \pm 1 / \cdot q$ &.$/ 1$ & r. & 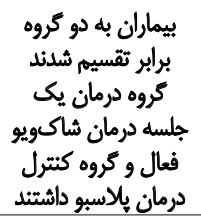 & كاستروكنميوس +..." & 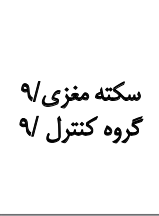 & $\begin{array}{l}\text { QLee } \\
\text { همكاران } \\
\text { Y.19 } \\
{[19]}\end{array}$ \\
\hline
\end{tabular}

للى عضلات إينتريسك دست را در دو گروه بيمار و عضلات فلكسور

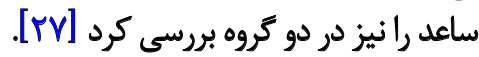

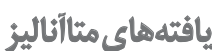

تحليل نتايج مطالعات واردشده به مثآآناليز با بررسى ثأثير شاكويو بر نمرات مقياس الصلاحشده آشورت مطات

درمجموع 11 مداخله كه ثأثير شاكويو روى نمرات مقياس
انتخاب ميزان شدت كاربردى توسط محقق ارائه نشده است. درمجموع دوازده مطالعه تأثير شاكويودرماني رابر نمرات مقياس

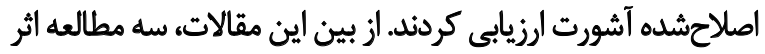

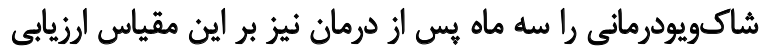
كردند [YU-YV] و اينترينسيك دست را ارزيابي كرد [YD].

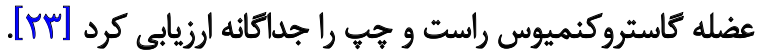




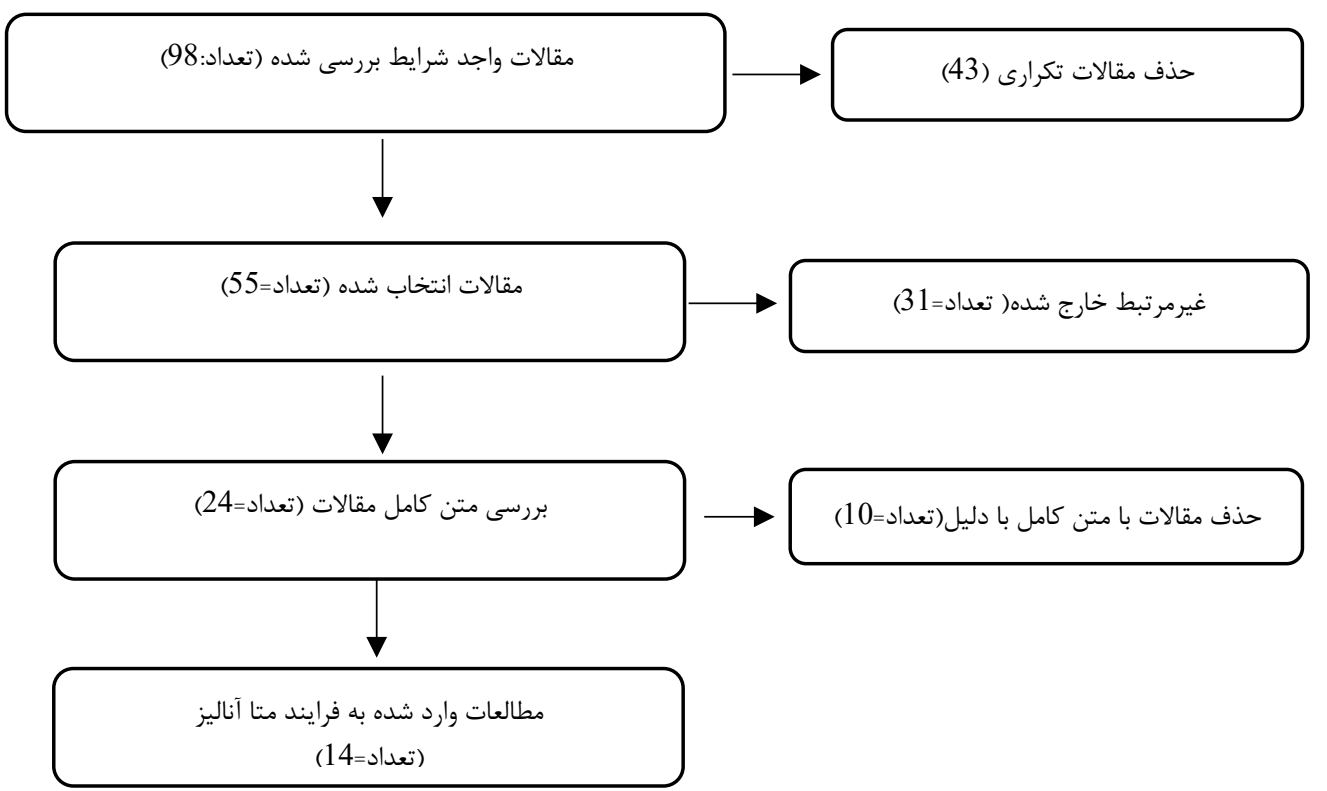

توانبخننى

تصوير ا. فلوجارت مراحل ورود مطالعات به مرور سيستماثيك و مثآناليز

$\mathrm{I}^{2}=100 \%, \mathrm{p}<0.001, \mathrm{SMD}=1.38$ with $95 \% \mathrm{Cl}:(0.80$,]

اصلاحشده آشورت راقبل و بعد از درمان و هفت مطالعه كه ثأثير (1.87]. تصوير شماره ب نمودار Forest plot ميزان تغييرات

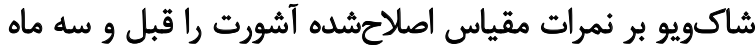

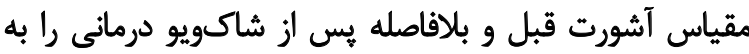

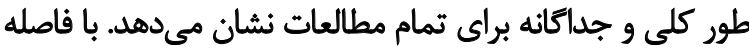
يس از شاكويودرمانى مورد بررسى قرار دارئد داده بودند در مثآ آناليز وارد شُّند.

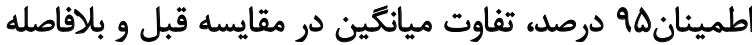

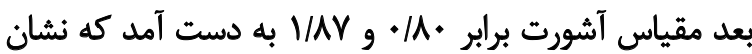
مىدهد ميانگين مقياس آشورت قبل و بلافاصله بعد از مداخله

نتايج متآآناليز نشاندهنده كاهش معنى دار مقياس اصلاحشده

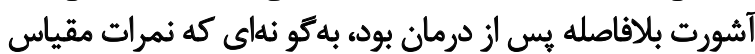

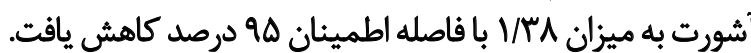

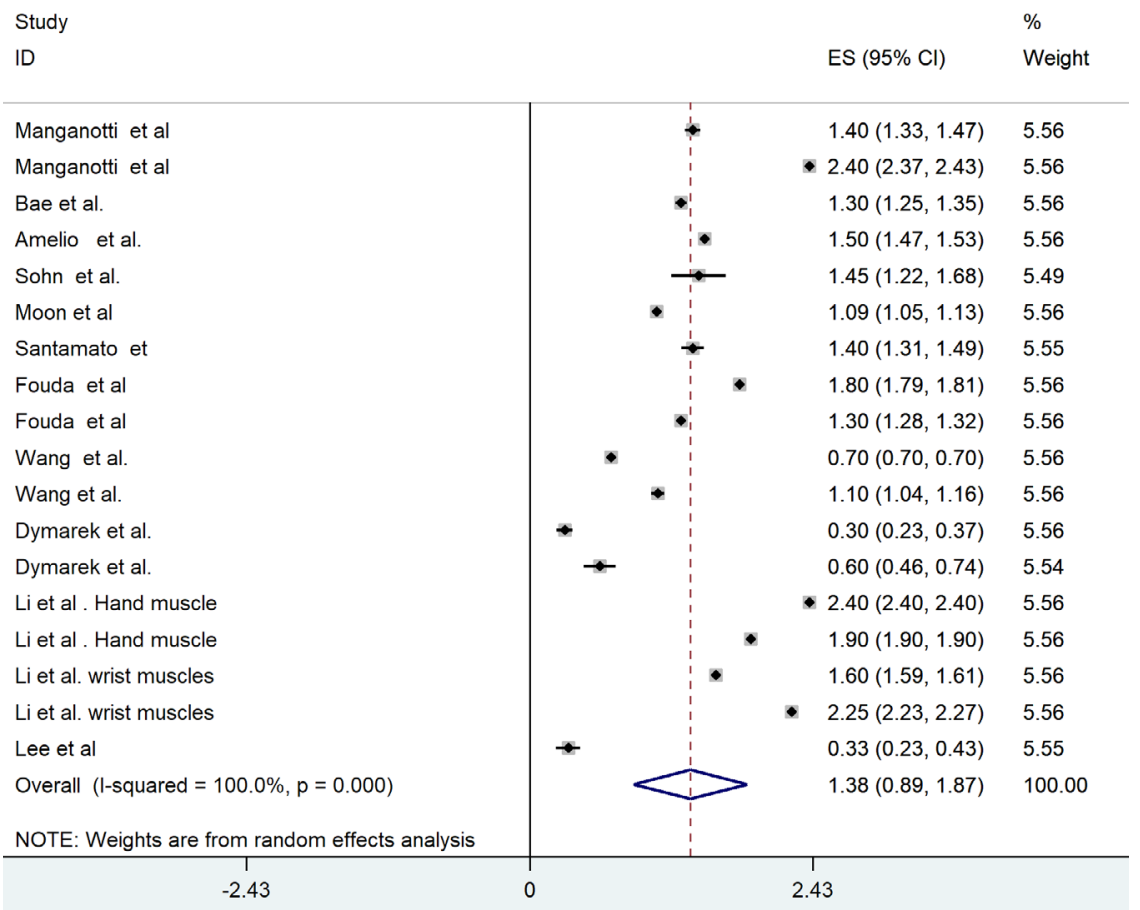




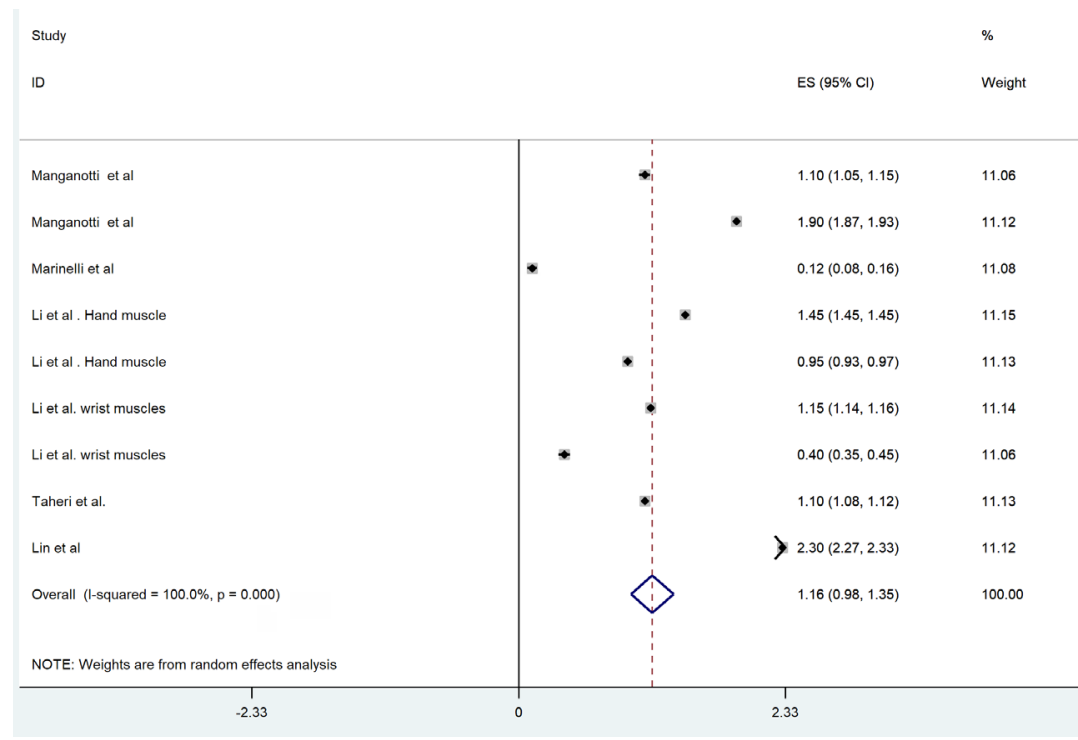

توانبخنتى

تصوير ب. نمودار Forest plot برآورد ميزان كاهش مقياس آشورت مقايسه قبل وبّ ماه بعد از درمان

تحليل نتايج مطالعات واردشده به متآناليز با بررسى تأثير شاكويو

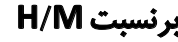

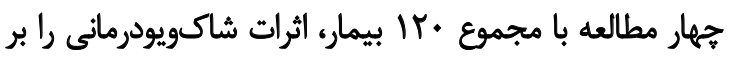

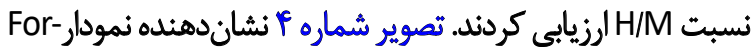

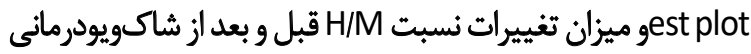

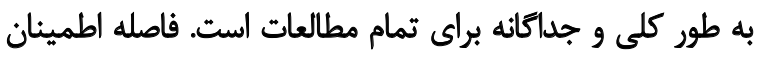

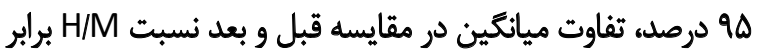

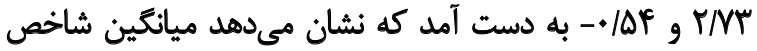
نسبت H/M Hبل و بعد از مداخله تفاوت معنى دار ندارد.

$\stackrel{\leftrightarrow}{*}$

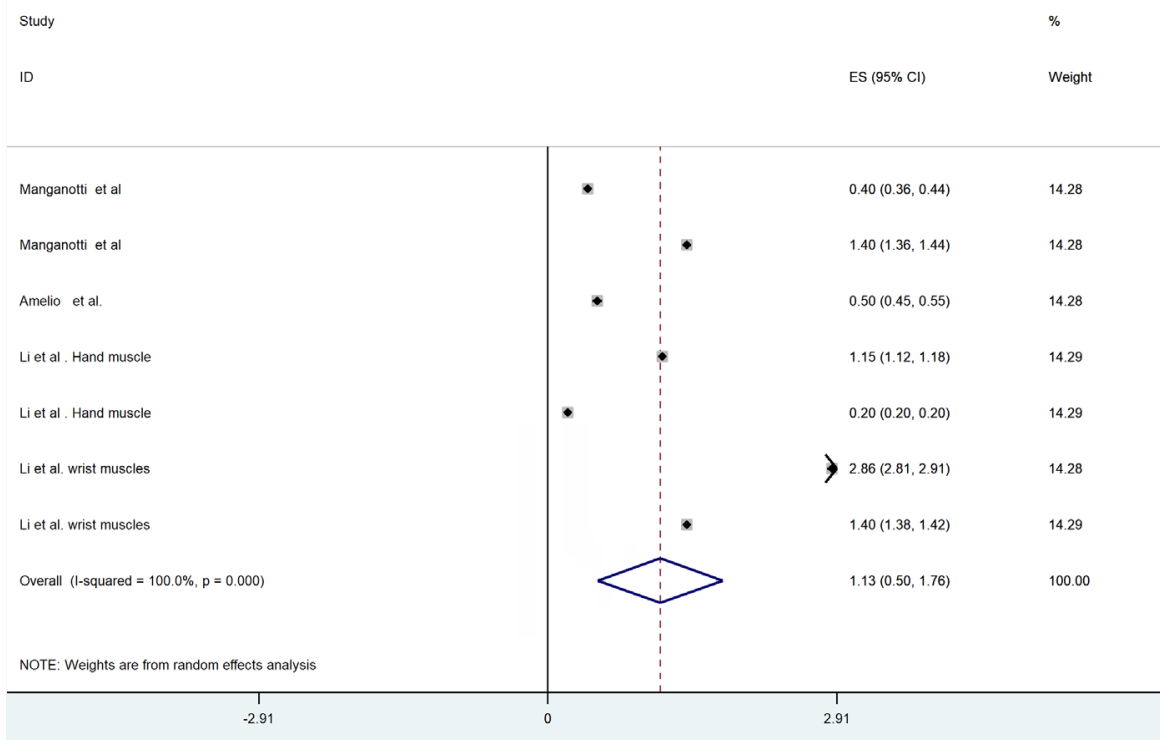

توانبخننى

تصوير ع. نمودار Forest plot برآورد ميزان تغييرات H/M Ratio قبل و بلافاصله بعد از درمان

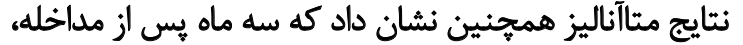

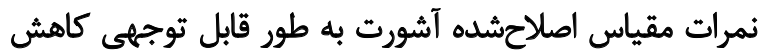

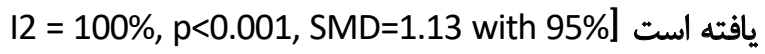

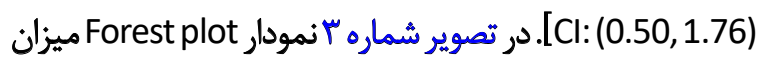

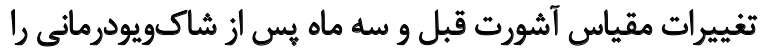

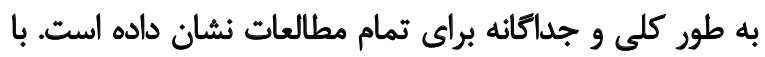

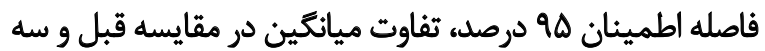

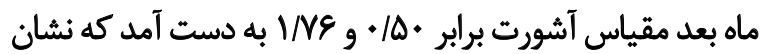

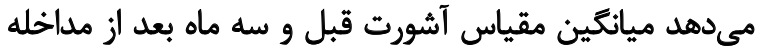

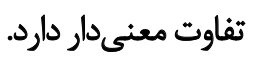


Fugl Meyer مقياس اصلاحشده آشورت، دامنه حركتى و معيار

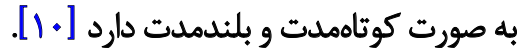
يافته ديكر اين مطالعه نشان داد كه تغييرات معنى دارى در تحريكيذيرى نورون حركتي آلفا (نسبت

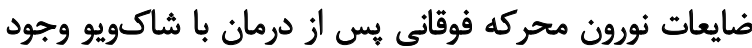

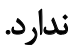
اين يافته مغاير با يافته مطالعه مرورى كوآ" و همكاران است

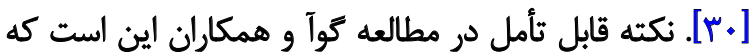

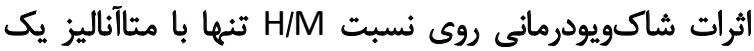

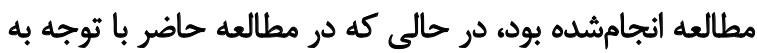

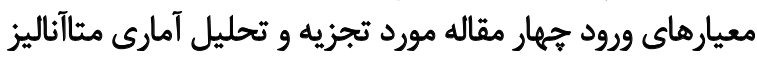

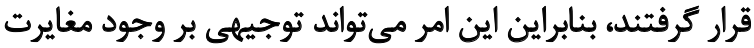
ميان يافته مطالعه حاضر با مطالعه كوآ باشد.

در اين زمينه بر اساس معيارهاى ورود، جهار مقاله كه به بررسى ني

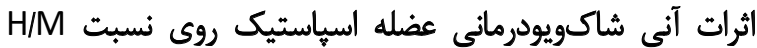

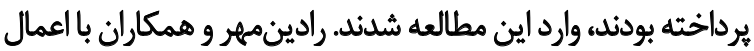

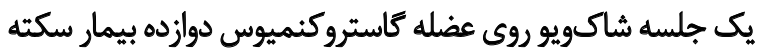
مغزى و ثبت نسبت H/M بلافاصله و يك ساعت يس إز داز درمان،

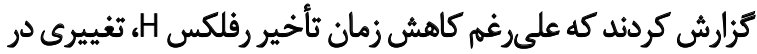

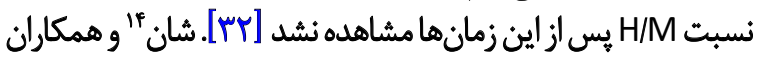

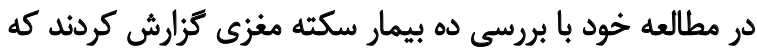

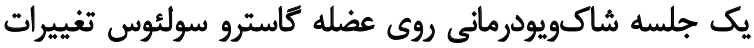

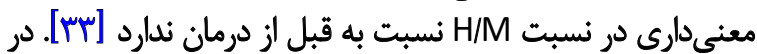

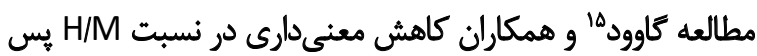

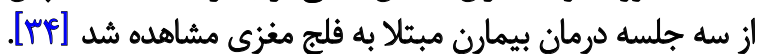

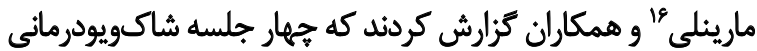

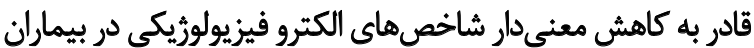

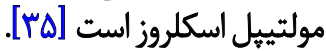

نكته قابل تأمل در مطالعاتى كه به بررسى نسبت H/M بر شدت

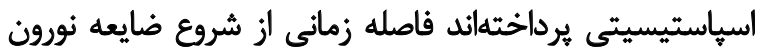

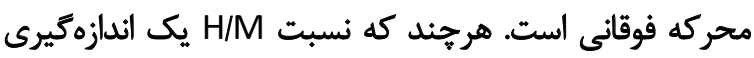

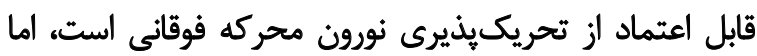

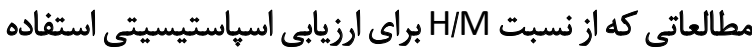

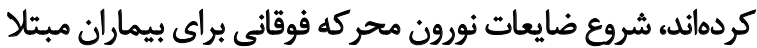

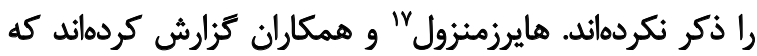

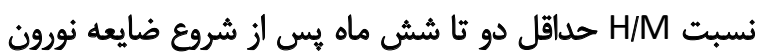

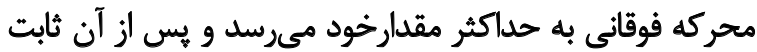

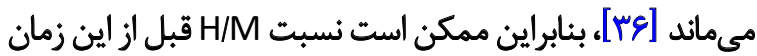

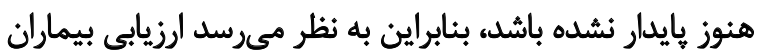

13. Guo

14. Shon

15. Gawad

16. Marinell

17. Hiersemenzel
به طور كلى يكى از مهمترين اهداف مطالعات مثآناليز حل

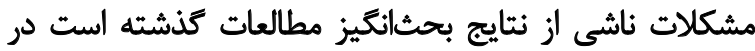

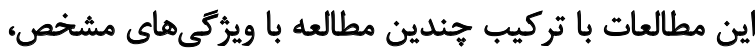

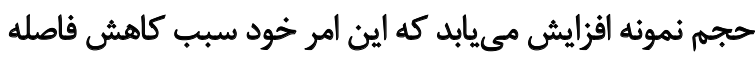

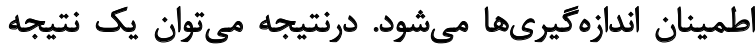
معتبر را از مطالعات كذشته ارائه كرد [بردئ. نتيجه مطالعه حاضر نشان داد كه درجه مقياس آشورت بـ آنس از

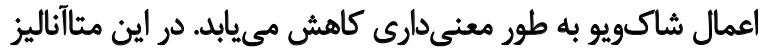

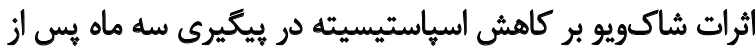

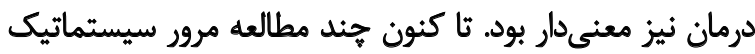

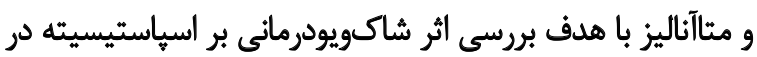

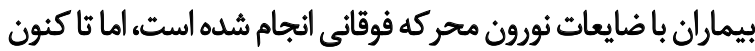

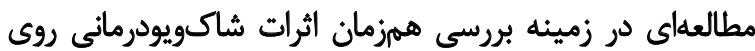

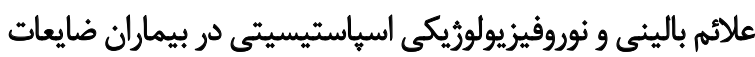
نورون محركه فوقانى با اتيولوريى هاي متفاوت انجام نشده است. نتايج ساير مطالعات مرورى كه اثر شاكويودرمانى رابر شدت

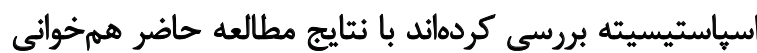

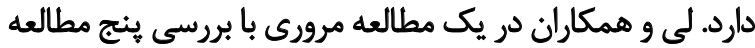

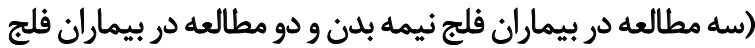

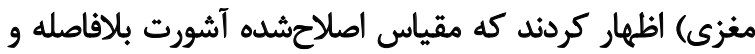

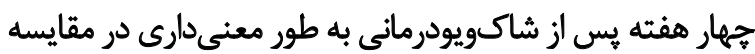

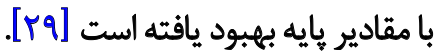
كاوود و همكاران در مطالعه خود به روش مرور سيستماتيك و

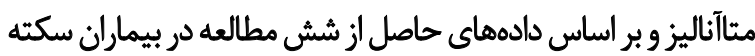

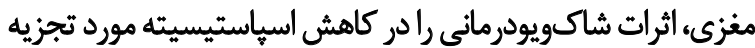

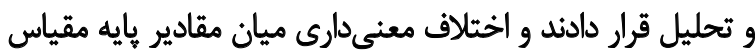

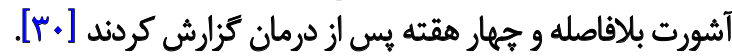
زانك "و همكاران با مرور سيستماتيك و متاآناليز هشت مطالعه

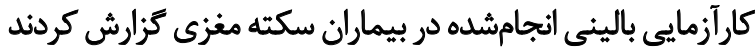

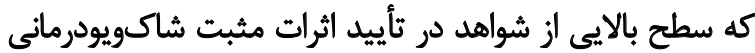

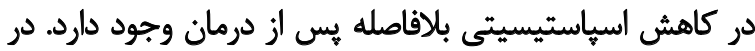

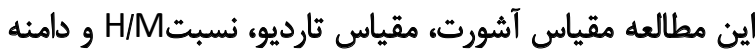
حركتى مفصل مورد تجزيه و تحليل قرار ترفته بود [آبـ].

در مرور سيستماتيك و مثا

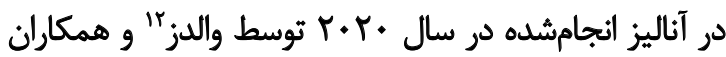

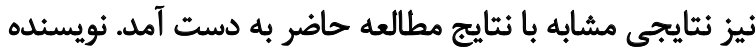

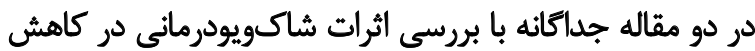

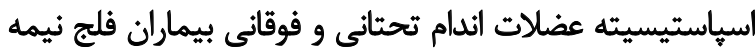

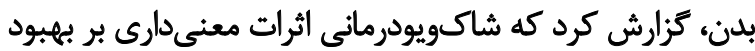


و تعداد شوك اعمال شده وجود ندارد و از طرفى در هيجيج كدام از

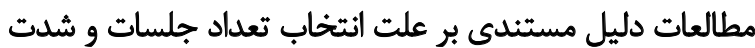

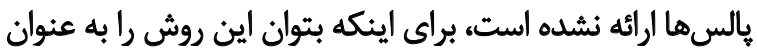

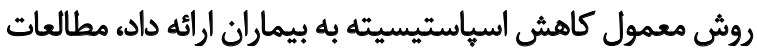

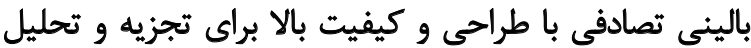

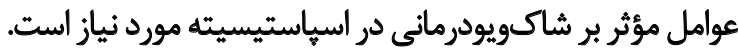
توصيه مىشود در مطالعات آينده كارآزمايىهاى بالينى با اين باين

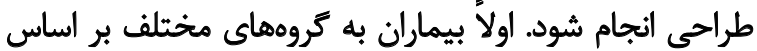

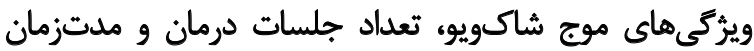

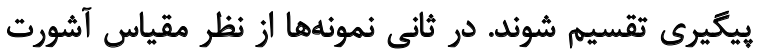

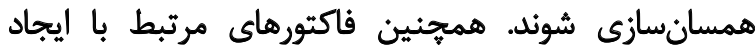

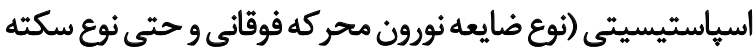
مغزى) نيز در انتخاب بيماران لحاظ شودي

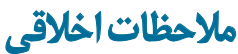

\section{بيروى ائز الصول اخلاق بُخوهش}

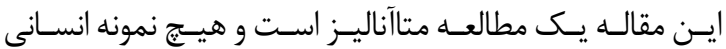

يـا حيوانى نــدارد.

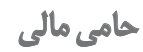

اين مقاله با حمايت مالى معاونت تحقيقات و فنآورى دانشكاه علوم يزشكى شهيد بهشتى انجام كرفته است.

$$
\text { مشاركت نويسند مكان }
$$

مفهومسازى و مديريت يروزه: ناهيد طحان؛ تحقيق و بررسى:

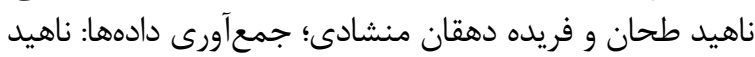

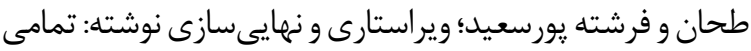
نويسندًان؛ تحليل آمارى: عليرضا اكبر زاده باغبان.

$$
\text { تقعارض مثأع }
$$

بنابر اظهار نويسندكان اين مقاله تعارض منافع ندارد.

$$
\text { تشكر و قدرواني }
$$

نويسندكان از معاونت تحقيقات و فنآورى دانشعاه علوم يزشكى شهيد بهشتى كمال تشكر را دارند.
از نظر شاخص نسبت H/M با توجه به زمان شروع عارضه، عامل

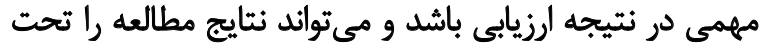

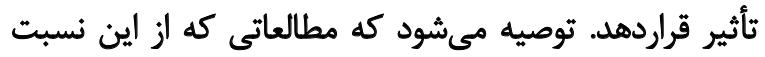

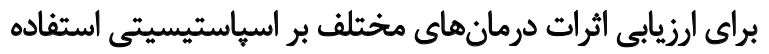

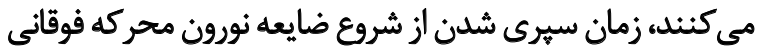

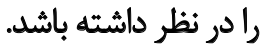

با وجودى كه نتايج تمامى مطالعات، تأييدكننده اثرات مثبت

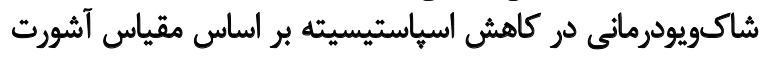

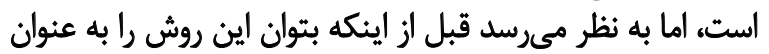

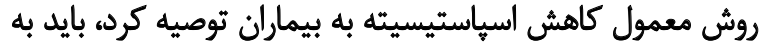
بسيارى از سؤالات باسخ داده شود.

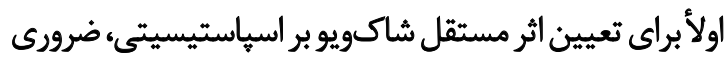

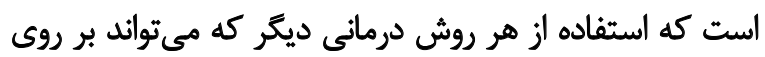

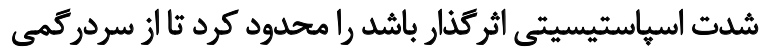

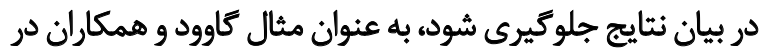

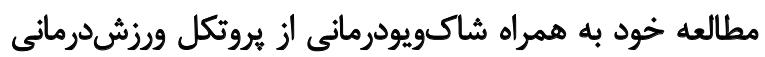

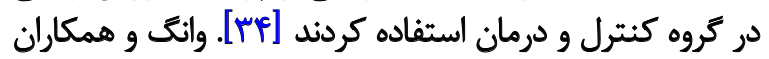

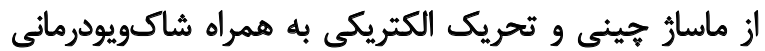

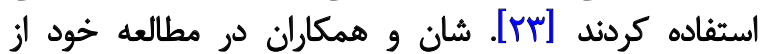

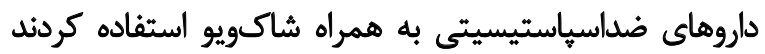

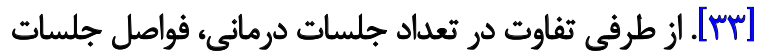

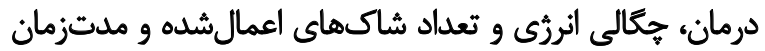

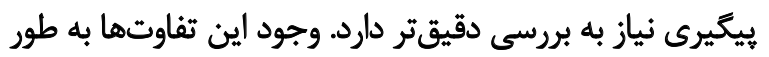

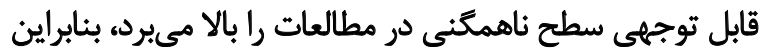

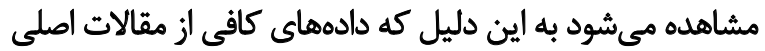

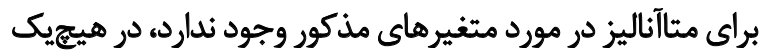

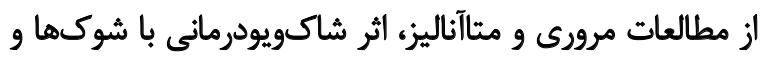
شدتهاى مختلف و طول درمانهاى متفاوت تجزيه و تحليل نشيه است

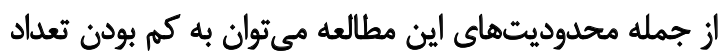

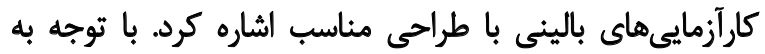

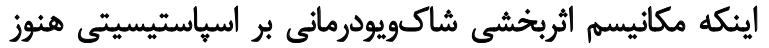

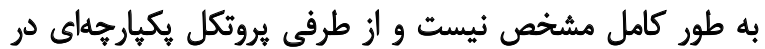

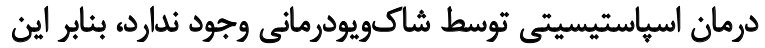
كارآزمايىهاى بيشتر باطراحى هائ مناسب در آينده مورد نياز است.

\section{نتيجنَّيرى}

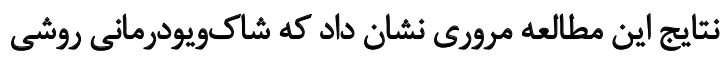

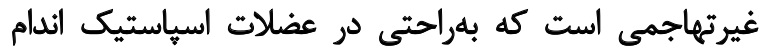

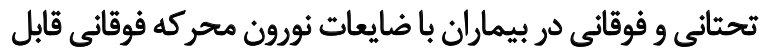

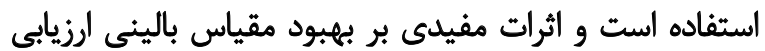

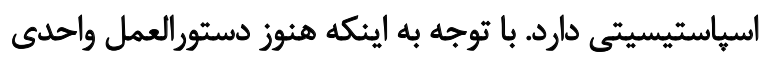
جهت درمان بيماران از نظر تعداد جلسات درمانى، شدت اندين انرئى 


\section{References}

[1] Katz RT, Rymer WZ. Spastic hypertonia: Mechanisms and measurement. Archives of Physical Medicine and Rehabilitation. 1989; 70(2):144-55. [DOI:10.5555/uri:pii:0003999389901342]

[2] Bar-On L, Molenaers G, Aertbeliën E, Van Campenhout A, Feys H, Nuttin B, et al. Spasticity and its contribution to hypertonia in cerebral palsy. BioMed Research International. 2015. [DOI:10.1155/2015/317047] [PMID] [PMCID]

[3] Katozian L, Tahan N, MohseniBandpei MA, JamBarsang S. Spasticity following stroke: A systematic review and meta-analysis. Journal of Mazandaran University of Medical Sciences. 2015; 25(123):230-45. https://www.researchgate.net/profile/ Mohammad-Mohseni-Bandpei/publication/280444247_Motor_ Learning_and_Movement_Performance_Aged_versus_Younger_Adults/links/55b6317208aec0e5f436ec17/Motor-Learningand-Movement-Performance-Aged-versus-Younger-Adults.pdf

[4] Rizzo MA, Hadjimichael OC, Preiningerova J, Vollmer TL. Prevalence and treatment of spasticity reported by Multiple Sclerosis Patients. Multiple Sclerosis Journal. 2004; 10(5):589-95. [DOI:10. 1191/1352458504ms1085oa] [PMID]

[5] Adams MM, Hicks AL. Spasticity after spinal cord injury. Spinal cord. 2005; 43(10):577-86. [DOI:10.1038/sj.sc.3101757] [PMID]

[6] Mukherjee A, Chakravarty A. Spasticity mechanisms-for the clinician. Frontiers in Neurology. 2010; 1:149. [DOI:10.3389/ fneur.2010.00149] [PMID] [PMCID]

[7] O'dwyer N, Ada L, Neilson P. Spasticity and muscle contracture following stroke. Brain. 1996; 119(5):1737-49. [DOI:10.1093/ brain/119.5.1737] [PMID]

[8] Goldstein EM. Spasticity management: an overview. Journal of Child Neurology. 2001; 16(1):16-23. [DOI:10.1177/08830738010 1600104] [PMID]

[9] Azimpour D, Tahan N. [The effect of three sessions shock wave therapy on spasticity and range of motion of lower limb in stroke patients (Persian)]. Tehran University Medical Journal TUMS Publications. 2019; 77(4):234-9. http://tumj.tums.ac.ir/article1-9767-en.html

[10] Cabanas-Valdés R, Calvo-Sanz J, Urrùtia G, Serra-Llobet P, PérezBellmunt A, Germán-Romero A. The effectiveness of extracorporeal shock wave therapy to reduce lower limb spasticity in stroke patients: A systematic review and meta-analysis. Topics in Stroke Rehabilitation. 2020; 27(2):137-57. [DOI:10.1080/10749357.2019 .1654242] [PMID]

[11] Ogden JA, Tóth-Kischkat A, Schultheiss R. Principles of shock wave therapy. Clinical Orthopaedics and Related Research. 2001; 387:8-17. [DOI:10.1097/00003086-200106000-00003] [PMID]

[12] Wang CJ. An overview of shock wave therapy in musculoskeletal disorders. Chang Gung Medical Journal. 2003; 26(4):220-32. http://cgmj.cgu.edu.tw/2604/260400.pdf

[13] Romeo P, Lavanga V, Pagani D, Sansone V. Extracorporeal shock wave therapy in musculoskeletal disorders: a review. Medical Principles and Practice. 2014; 23(1):7-13. https://www.karger.com/ Article/Abstract/355472
[14] Takahashi N, Ohtori S, Saisu T, Moriya H, Wada Y. Second application of low-energy shock waves has a cumulative effect on free nerve endings. Clinical Orthopaedics and Related Research (19762007). 2006; 443:315-9. [DOI:10.1097/01.blo.0000188064.56091. a7] [PMID]

[15] Kenmoku T, Ochiai N, Ohtori S, Saisu T, Sasho T, Nakagawa K, et al. Degeneration and recovery of the neuromuscular junction after application of extracorporeal shock wave therapy. Journal of Orthopaedic Research. 2012; 30(10):1660-5. [DOI:10.1002/ jor.22111] [PMID]

[16] Poursaeed F, Tahan N. Assessment of spasticity in patients with stroke (systematic review of literature). Journal of Rehabilitation Medicine. 2016; 5(1):190-208. [DOI:10.22037/JRM.2016.1100265]

[17] Voerman GE, Gregorič M, Hermens HJ. Neurophysiological methods for the assessment of spasticity: The Hoffmann reflex, the tendon reflex, and the stretch reflex. Disability and Rehabilitation. 2005; 27(1-2):33-68. [DOI:10.1080/09638280400014600] [PMID]

[18] Rekand T. Clinical assessment and management of spasticity A review. Acta Neurologica Scandinavica. 2010; 122(s190):62-6. [DOI:10.1111/j.1600-0404.2010.01378.x] [PMID]

[19] Lee CH, Lee SH, Yoo JI, Lee SU. Ultrasonographic evaluation for the effect of extracorporeal shock wave therapy on gastrocnemius muscle spasticity in patients with chronic stroke. PM \& R. 2019; 11(4):363-71. [DOI:10.1016/j.pmrj.2018.08.379] [PMID]

[20] Yoo SD, Kim HS, Jung PK. The effect of shock wave therapy on upper limb spasticityin the patients with stroke. Journal of Korean Academy of Rehabilitation Medicine. 2008; 32(4):406-10. https:// www.koreamed.org/SearchBasic.php?RID=2325131

[21] Liberati A, Altman DG, Tetzlaff J, Mulrow C, Gøtzsche PC Ioannidis JP, et al. The PRISMA statement for reporting systematic reviews and meta-analyses of studies that evaluate health care interventions: explanation and elaboration. Journal of Clinical Epidemiology. 2009; 62(10):e1-e34. [DOI:10.1016/i.jclinepi.2009.06.006] [PMID]

[22] Subramanian SK, Caramba SM, Hernandez OL, Morgan QT, Cross MK, Hirschhauser CS. Is the Downs and Black scale a better tool to appraise the quality of the studies using virtual rehabilitation for post-stroke upper limb rehabilitation? Paper presentetd at: 2019 International Conference on Virtual Rehabilitation (ICVR). 2019 July 21; Tel Aviv, Israel. [DOI:10.1109/ICVR46560.2019.8994724]

[23] Wang T, Du L, Shan L, Dong H, Feng J, Kiessling MC, et al. A prospective case-control study of radial extracorporeal shock wave therapy for spastic plantar flexor muscles in very young children with cerebral palsy. Medicine. 2016; 95(19):e3649. [DOI:10.1097/ MD.0000000000003649] [PMID] [PMCID]

[24] Moon SW, Kim JH, Jung MJ, Son S, Lee JH, Shin H, et al. The effect of extracorporeal shock wave therapy on lower limb spasticity in subacute stroke patients. Annals of Rehabilitation Medicine. 2013; 37(4):461. [DOI:10.5535/arm.2013.37.4.461] [PMID] [PMCID]

[25] Manganotti P, Amelio E. Long-term effect of shock wave therapy on upper limb hypertonia in patients affected by stroke. Stroke. 2005;36(9):1967-71. [DOI:10.1161/01.STR.0000177880.06663.5c] [PMID] 
[26] Amelio E, Manganotti P. Effect of shock wave stimulation on hypertonic plantar flexor muscles in patients with cerebral palsy: A placebo-controlled study. Journal of Rehabilitation Medicine. 2010; 42(4):339-43. [DOI:10.2340/16501977-0522] [PMID]

[27] Li TY, Chang CY, Chou YC, Chen LC, Chu HY, Chiang SL, et al. Effect of radial shock wave therapy on spasticity of the upper limb in patients with chronic stroke: A prospective, randomized, single blind, controlled trial. Medicine. 2016; 95(18):e3544. [DOI:10.1097/MD.0000000000003544] [PMID] [PMCID]

[28] Mao LF, Zheng QQ. The characteristics, methods of meta-analysis and its applications. Chinese Journal of Applied Psychology. 2005; 11(4):354-9. https://en.cnki.com.cn/Article_en/CJFDTotal-YXNX200504011.htm

[29] Lee JY, Kim SN, Lee IS, Jung H, Lee KS, Koh SE. Effects of extracorporeal shock wave therapy on spasticity in patients after brain injury: A meta-analysis. Journal of Physical Therapy Science. 2014; 26(10):1641-7. [DOI:10.1589/jpts.26.1641] [PMID] [PMCID]

[30] Guo P, Gao F, Zhao T, Sun W, Wang B, Li Z. Positive effects of extracorporeal shock wave therapy on spasticity in poststroke patients: a meta-analysis. Journal of Stroke and Cerebrovascular Diseases. 2017; 26(11):2470-6. [DOI:10.1016/j.jstrokecerebrovasdis.2017.08.019] [PMID]

[31] Xiang J, Wang W, Jiang W, Qian Q. Effects of extracorporeal shock wave therapy on spasticity in post-stroke patients: A systematic review and meta-analysis of randomized controlled trials. Journal of Rehabilitation Medicine. 2018; 50(10):852-9. [DOI:10.2340/16501977-2385] [PMID]

[32] Radinmehr H, Nakhostin Ansari N, Naghdi S, Olyaei G, Tabatabaei A. Effects of one session radial extracorporeal shockwave therapy on post-stroke plantarflexor spasticity: A single-blind clinical trial. Disability and Rehabilitation. 2017; 39(5):483-90. [DOI:10 .3109/09638288.2016.1148785] [PMID]

[33] Sohn MK, Cho KH, Kim YJ, Hwang SL. Spasticity and electrophysiologic changes after Extracorporeal Shock Wave Therapy on gastrocnemius. Annals of Rehabilitation Medicine. 2011; 35(5):599. [DOI:10.5535/arm.2011.35.5.599] [PMID] [PMCID]

[34] Gawad HAA, Mohammed A, Karim A. Shock wave therapy for spastic plantar flexor muscles in hemiplegic cerebral palsy children. Egyptian Journal of Medical Human Genetics. 2015; 16(3):269-75. [DOI:10.1016/j.ejmhg.2014.12.007]

[35] Marinelli L, Mori L, Solaro C, Uccelli A, Pelosin E, Curra A, et al. Effect of radial shock wave therapy on pain and muscle hypertonia: A double-blind study in patients with multiple sclerosis. Multiple Sclerosis Journal. 2015; 21(5):622-9. [DOI:10.1177/1352458514549566] [PMID]

[36] Hiersemenzel LP, Curt A, Dietz V. From spinal shock to spasticity: Neuronal adaptations to a spinal cord injury. Neurology. 2000; 54(8):1574-82. [DOI:10.1212/WNL.54.8.1574] [PMID]

[37] BaeHS,LeeJM,LeeKH. [The effects of extracorporeal shock wave therapy on spasticity in chronic stroke patients (Korean)]. Journal of Korean Academy of Rehabilitation Medicine. 2010; 34(6):6639. https://kmbase.medric.or.kr/KMID/0361420100340060663

[38] Santamato A, Francesca Micello M, Panza F, Fortunato F, Logroscino G, Picelli A, et al. Extracorporeal shock wave therapy for the treatment of poststroke plantar-flexor muscles spasticity: a prospective open-label study. Topics in Stroke Rehabilitation. 2014; 21(sup1):S17-S24. [DOI:10.1310/tsr21S1-S17] [PMID]

[39] Fouda KZ, Sharaf MA. Efficacy of radial shock wave therapy on spasticity in stroke patients. International Journal of Health and Rehabilitation Sciences. 2015; 4(1):19-26. [DOI:10.5455/ ijhrs.000000072]

[40] Dymarek R, Taradaj J, Rosińczuk J. Extracorporeal shock wave stimulation as alternative treatment modality for wrist and fingers spasticity in poststroke patients: A prospective, open-label, preliminary clinical trial. Evidence-Based Complementary and Alternative Medicine. 2016; 2016:10 [DOI:10.1155/2016/4648101] [PMID] [PMCID] 